\title{
SERUM PROTEINS: A Review
}

BY

\author{
J. R. MARRACK AND H. HOCH \\ From the Department of Chemical Pathology, London Hospital Medical College
}

$10 \times 10$

$1 0 \longdiv { 6 }$

(RECEIVED FOR PUBLICATION, JUNE 3, 1949)

Introduction

\section{Electrophoresis : Method and Interpretation}

162

II. Fractionation by Precipitation Methods ...

163

Salting Out

Low Salt Concentrations

Quantitative Methods

Low-Temperature-Low-Salt-Low-Dielectric-Constant Fractionation

III. Normal Concentrations of Serum Proteins

167

Total Protein

Electrophoretic Fractions

Serum Proteins in Pregnancy and Infancy

For many years it has been realized that serum globulin is not a single homogeneous protein, but comprises a variety of proteins which have different physical, chemical, and physiological properties. The salt fractionation methods that have been used for many years do not yield fractions which are sharply distinguished one from another in any properties. A striking example is that of the fractionation of diphtheria antitoxic serum with ammonium sulphate; antitoxin is found in a series of fractions ranging from that precipitated between 30 and $35 \%$ saturation to that precipitated between 52 and $56 \%$ saturation (Barr and Glennie, 1931).

During recent years new methods have been used for the separation and study of the proteins of serum and plasma. In particular the moving boundary method of electrophoretic analysis developed by Tiselius (1937) raised great hopes, for by this method at least five fractions of different mobility can be recognized in human serum ; the mobilities of these fractions are distinct and little material of intermediate mobility can be c*
IV. Composition, Physical, and Physiological $\begin{array}{llllll}\text { Properties } & \ldots & \ldots & \ldots & \ldots & 168\end{array}$ Composition Molecular Weights Immunology Physiological Properties

V. Serum Proteins in Disease ... $\ldots$
Response to Injury and Infection Effect of Deficiency of Protein

Lipaemia

Liver Disease

Myelomatosis

Miscellaneous Diseases

Other Abnormal Proteins

VI. Flocculation Reactions ' $\ldots \quad \ldots \quad \ldots \quad \ldots \quad 185$

Erythrocyte Sedimentation Rate

$\begin{array}{llllll}\text { Discussion } \ldots & \ldots & \ldots & \ldots & \ldots & \ldots\end{array}$

detected. Cohn and his colleagues at Harvard have studied the factors that affect the solubility of proteins. On the basis of these studies they have developed a method of separation of proteins by independent variation of these factors. This method has revealed the presence in serum of a great variety of distinct proteins. It has now been used extensively and on a large scale for the preparation of active fractions relatively free from other protein. Methods have been devised by which the molecular weights of protein molecules can be calculated and tentative estimates can be made of their shapes and sizes.

The separation of fractions by electrophoresis is based on one property only, that is, mobility in an electric field. The molecules contained in a fraction which, on the basis of mobility, is homogeneous, may have different shapes, weights, and sizes, different chemical compositions and different physiological properties. The globulin fractions separated by Cohn's methods and, still more, those separated by salt fractionation, contain proteins of different mobilities. The grouping of 
serum globulins, therefore, depends on the choice of property on the basis of which they are classified.

The mobilities of the components of the fractions prepared by Cohn's methods have been measured. A very large number of abnormal sera have been studied by electrophoresis; from these results it is possible to draw conclusions as to the changes of electrophoretic pattern that may be expected in various types of disease, and the significance of these changes. Few abnormal sera have been studied by the other new methods. We will, therefore, use the electrophoretic patterns as the basis of discussion in this article.

Comprehensive reviews of investigations into the concentration, distribution, and significance of proteins in serum have been published by Janeway (1943), Stern and Reiner (1946), Luetscher (1947), and Gutman (1948).

\section{Electrophoresis : Method and Interpretation}

The object of electrophoresis is to demonstrate the presence of constituents which have different mobilities and to measure the relative concentrations of these constituents. The conditions of $p \mathrm{H}$ and salt concentration influence the results and they have to be specified. The range of $p \mathrm{H}$ commonly used for plasma or serum is between 7.7 and 8.6 ; in this $p H$ range all serum proteins carry negative charges and therefore move towards the anode. The salt concentration usually chosen is equivalent to an ionic strength of 0.1 or $0.2 .^{*}$ The experiments are made in the special apparatus designed by Tiselius which consists of a U-tube with a rectangular cross section, the upper ends of which are connected to two electrodes. The solution to be analysed is run into the bottom part of the U-tube, buffer solution is placed on it and in the remaining space, including the electrode vessels.

At the beginning there is one boundary between the protein solution and the supernatant buffer in each limb of the U-tube (Fig. 1a). On passing an electric current these two boundaries move away from the original positions at velocities equal to the velocities of the protein ions below these moving boundaries. If several protein constituents of different mobilities are present the original boundaries will split into several boundaries moving with different speeds. In addition to these moving boundaries there are two almost stationary boundaries, $\delta$ and $\epsilon$, which are due to changes in conductivity at the positions of the original boundaries (Fig. 1). Before it is put in the $U$-tube the protein solution is dialysed against the buffer. In order to reduce to a minimum convection currents arising from differences in temperature within the U-tube between the inner and the marginal parts

*The ionic strength is defined by $\frac{1}{2}\left(c_{1} z_{1}{ }^{2}+c_{2} z_{z}{ }^{2}+\ldots\right)$ where $c_{1}, c_{2}, \ldots$ are the ion concentrations and $z_{1}, z_{2}, \ldots$. are the valencies.

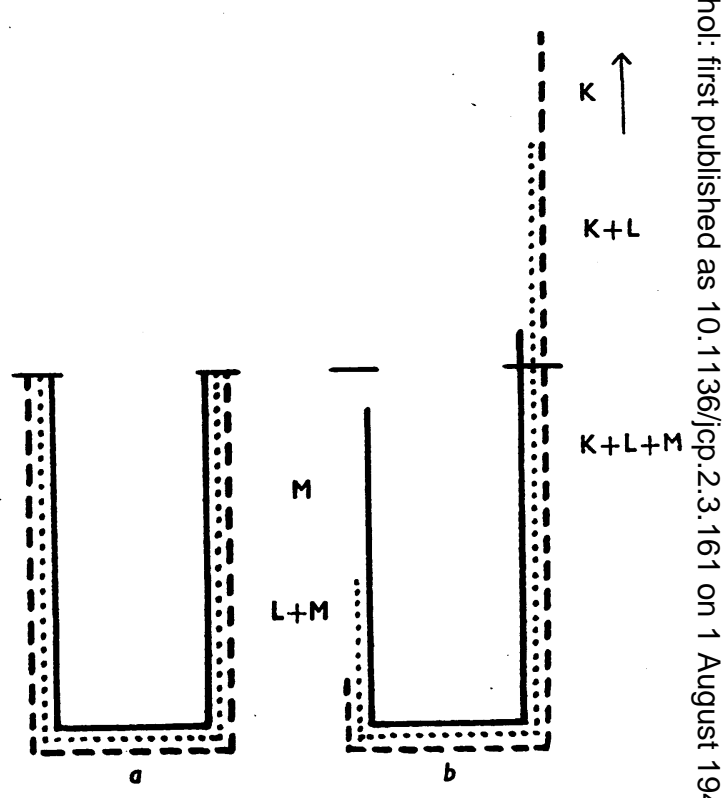

FIG. 1.-Distribution of three components, K, L, ande $M$, of different mobilities: (a) Before electro: phoresis; (b) after electrophoresis.

during the passage of the current, the U-tube is immersed in a water-bath of a temperature near the density maximum of the solution $\left(0-4^{\circ} \mathrm{C}\right.$.).

The methods of observing the number and positions of the boundaries and of measuring the relative concentrations of the fractions are based on the change of refractive index produced by the change in the concentration of protein at the boundary. Or? account of this change of refractive index a horizontas. ray of light passing through the tube is deflected? downwards. The extent of the deflection depends orf the rate of change of the refractive index. In the space immediately above and below the boundary the concentration does not change and a ray of light pass $₹$ ing through the tube is not deflected. In Thovert's cylindrical lens (Thovert, 1914; Philpot, 1938 ? Svensson, 1939) and in Longsworth's Schlieren scant ning (1939) methods the vertical deflection is trans lated by optical and mechanical devices into a lateraf deflection which is recorded on a screen. The्र boundary appears on the screen as a peak. Op migration the sharpness of the peak changes. VarieN ation in conductivity and in $p H$ have each the effeç of sharpening the peak in one limb and of broaden ing it in the other. These effects may be in the oppo site or in the same direction. Spreading by diffusions is superimposed in both limbs. If a boundary peak remains single during migration over a long distanceit is usually inferred that the protein is electro phoretically homogeneous. But this need not neces $\Omega$ sarily be the case, since a mixture of similar proteins the mobilities of which are distributed in a smootho frequency curve, can also show a single peak after 
migration over a long distance. Criteria to define the degree of non-homogeneity have been proposed. (For literature see Alberty, 1948.)

Fig. 2 shows the concentration distribution along the vertical direction in a boundary. The difference between the concentrations at $A$ and that at $A^{\prime}$ is proportional to the difference between the refractive indices at $A$ and that at $A^{\prime}$. This can be shown to be proportional to the area under the peak $\mathrm{ADA}^{\prime}$. When the protein solution used is a solution of serum pro-

C

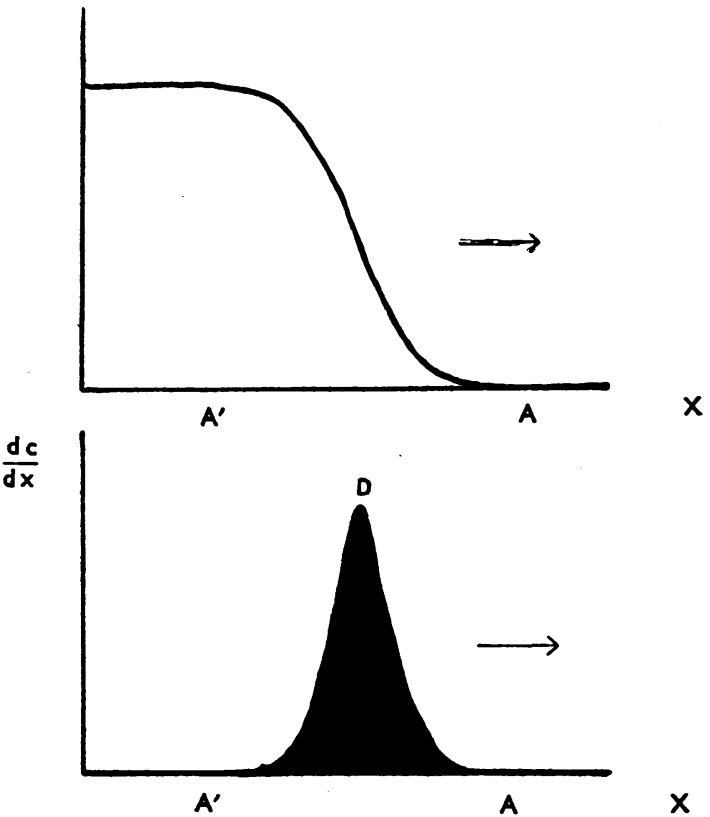

Fig. 2.-Concentration-distribution in a boundary, and corresponding peak formed on plate.

teins the components that have different mobilities are represented by peaks as in Fig. 3. They are called albumin, $a_{1^{-}}$(Longsworth, 1942), $a_{2}-, \beta$ - and $\gamma$-globulin. In order to separate the $a_{1}$-globulin from the albumin a diethybarbiturate buffer of $p \mathrm{H} 8.6$ is used (Longsworth, 1942). When the phosphate buffer is used at a $p \mathrm{H}$ lower than 8.0 the $a_{1}$-globulin peak does not separate from the albumin peak; the "albumin" therefore includes $a_{1}$-globulin.* Subsequently it has been shown that each component is composed of a group of proteins the mobilities of which differ slightly. Frequently two peaks can be distinguished in the region of the $\beta$-globulin boundary. The faster has been called $\beta_{1}-$ and the slower $\beta_{2}-$. A small component normally seen in human sera between the $\beta_{2}$ - and the $\gamma$-globulins has been designated as $\beta_{2}-$, but is now called $\gamma_{4}$ - (Deutsch et al., 1946). If plasma is used the fibrinogen is represented is a peak, $\varnothing$, which includes

*Throughout this review we will use the term "“globulin "(without a numerical suffix) to mean $a_{2}$-globulin separated at a $p \mathrm{H}$ not exceeding 8.0 ; in these instances, the $a_{1}$-globulin is included in the "albumin." the $\gamma_{1}$-globulin and lies between the $\beta$ - and $\gamma$-globulin. The concentrations of these components are proportional to the areas (measured with a planimeter) under these peaks; the relative concentrations are calculated from the relative proportions of these areas, and, if the total concentration of protein in serum has been determined, the absolute concentrations of these fractions can be calculated.* This simple statement needs some qualification. In the first place it assumes that the rate of change of refractive index with change of concentration (specific refractive increment) is the same for each protein and that no gradients of refractive index are produced across the boundaries by concentration gradients of other substances. In the second place, the molecules which move in groups and cause the changes of refractive index are not simple proteins, in the sense of compounds built of amino-acids, but are aggregates of protein, carbohydrate, and lipids more or less firmly united. The assumption that the specific refractive increment is the same for each protein is approximately correct if the concentration of "protein" used as a basis of calculation is the weight of the total protein-lipid-carbohydrate aggregate that moves as a unit. But the traditional methods of reckoning amounts of proteins are based on the amounts of nitrogen that they contain, or on the dry weight of the protein-carbohydrate complex left after extraction of the lipids. As the amounts of lipid in the $a$ - and $\beta$-globulins of serum are larger than the amounts in the albumin and $\gamma$-globulin, the relative proportions of $\alpha$ - and $\beta$-globulin calculated from the areas of the peaks are higher than would be found if the proportions were calculated from the amounts of nitrogen in these fractions. This difference in method of reckoning accounts for part of the difference between the albumin/globulin ratios found by salt fractionation and by electrophoresis; the difference becomes large when the amount of lipid in the serum is high. Other factors affect the apparent concentrations and mobilities. All that need be said here is that for comparable results ionic strength and protein concentrations must be kept within certain limits. Experiments to determine these limits have been made by Perlmann and Kaufman (1945), Svensson (1946), Koenig et al. (1946), and others.

\section{Fractionation by Precipitation Methods}

It is not generally practicable to use electrophoresis as a routine method of examination. When interest was focused on the reduction of serum proteins in nephrosis it was sufficient to measure the total concentration of proteins. Now that it is realized that in some diseases the concentration of albumin may be very low, although the total concentration of protein is not reduced,

*The reproducibility of the measurements can be assessed from the data given by Dole (1944), Seibert et al. (1947), and others. The error in the estimate of the albumin is usually within $\pm 2 \%$; that of any other component, if 10 or $20 \%$ of the total, within $\pm 5 \%$, depending on the resolution of the peaks. 
and that the concentration of one electrophoretic fraction of the globulin may be changed without changes of the concentrations of the others, the relation of fractions separated by suitable routine methods to electrophoretic fractions must be considered.

Salting Out.-The fractions separated by precipitation with strong salt solutions are not homogeneous. In the earliest investigations Tiselius (1937) found that the globulin fraction, precipitated from horse pattern very little. (In the serum studied little prơ tein, Howe's "euglobulin,"* was precipitated by the concentration of sulphate.) When the concentration was raised to $17.4 \%$ about one-half of the $\gamma$-globulig. a quarter of the $\beta-$, and none of the a-globulin ws. precipitated. This fraction includes Howe's pseudes globulin I. All the $\gamma$-, three-quarters of the $\beta$-, arif one-quarter of the a-globulin including Howegis pseudoglobulin II were precipitated by $21.5^{\circ}$ sufPphate. The residual solution, containing How $\overrightarrow{0}$ "albumin," contained $\alpha$ - and $\beta$-globulin. Dole (1944)

TABLE I

DISTRIBUTION OF ELECTROPHORETIC COMPONENTS (g./100 ml. OF ORIGINAL SERUM) IN FRACTIONS PRECIPITATED WITH AMMONIUM SULPHATE FROM NORMAL HUMAN SERUM (NEURATH $E \Gamma \quad A L ., 1947$ )

\begin{tabular}{|c|c|c|c|c|c|c|}
\hline & & \multirow{2}{*}{ Albumin } & \multicolumn{4}{|c|}{ Globulin } \\
\hline & & & $\alpha_{1}$ & $\alpha_{2}$ & $\beta$ & $\gamma$ \\
\hline \multicolumn{2}{|c|}{ Whole Serum } & 3.52 & 0.4 & 1.07 & 0.80 & 1.41 \\
\hline \multicolumn{2}{|c|}{ Fractions Precipitated Betwsen } & & & & & \\
\hline$\stackrel{\text { Mlolar }}{ }$ Concentrations & $\underset{(\%)}{\text { Saturation }}$ & & & & & \\
\hline $0-1.4$ & 0-34 & 0 & 0 & 0.04 & 0.09 & 0.62 \\
\hline $\begin{array}{l}1.4-1.7 \\
1.7-2.1 \\
2.1-\end{array}$ & $\begin{array}{l}34-42 \\
42-51 \\
51-\end{array}$ & $\begin{array}{l}0.05 \\
0.10 \\
2.28\end{array}$ & $\begin{array}{c}0 \\
0.12 \\
0.38\end{array}$ & $\begin{array}{l}0.22 \\
0.33 \\
0.22\end{array}$ & $\begin{array}{l}0.08 \\
0.20\end{array}$ & $\begin{array}{c}0.09 \\
0\end{array}$ \\
\hline
\end{tabular}

serum by $30 \%$ saturation with ammonium sulphate, contained some albumin, and that $25 \%$ of the protein not precipitated by $50 \%$ saturation was globulin. Cohn, McMeekin, and colleagues (1940), and Svensson (1941) found that the fractions of the globulin precipitated between various concentrations of ammonium sulphate contained all three of the electrophoretic components. The distribution in the fractions precipitated from human serum are given in Table I. Jager and Nickerson (1948) found that about three-quarters of the globulin precipitated by $33 \%$ saturated ammonium sulphate was $\gamma$-globulin; the precipitate also contained 11 to $14 \%$ of $\beta$ globulin and 5 to $16 \%$ of $a_{1}-$, and $\alpha_{2}$-globulin. The heterogeneity of these salt-precipitated fractions is also shown by the fact that a $\beta$-globulin, which contains the mid-piece of complement, makes up a considerable part of the globulin precipitated from human and guinea-pig serum by $34 \%$ saturated ammonium sulphate (1.39M.) at a $p \mathrm{H}$ of about 6.1 (Pillemer et al., 1941, 1943).

In Kekwick's (1940) method of preparing $\gamma$-globulin from normal human serum the precipitate formed with $12 \%$ sodium sulphate contained $5 \%$ of $\beta$ - and a-globulin. In the course of their study of the fractionation of normal human sera by Howe's (1921) method Gutman and his colleagues (1941) found that $13.5 \%$ sodium sulphate changed the electrophoretic also found that Howe's albumin contained more than one globulin fraction.

In other studies of human serum, such as tha: Kibrick and Blonstein (1948), the amounts of protet: precipitated by various concentrations of sodium sut phate have been compared with the amounts of tis fractions found by electrophoresis. The fact that the amount of protein precipitated by a given concentrf tion of a salt is equal to the amount of some electro phoretic fraction does not imply that this precipitate is electrophoretically homogeneous.

Low Salt Concentration.-The amount of globuli precipitated from serum by dilution or dialysis again solutions of low salt concentration depends on the $p \mathrm{H}$ and ionic strength. Thus the so-called "en piece" of guinea-pig complement is not precipitate at $p \mathrm{H} 5.2$ and an ionic strength of 0.075 but is precipt tated at this $p \mathrm{H}$ when the ionic strength is reduced 0.01 (Pillemer et al., 1941). Erickson et al. (1940) found that in euglobulin, precipitated from syphilit serum by dilution and the passage of $\mathrm{CO}_{2}$ or by addẹ tion of $\mathrm{HCl}$ to $p \mathrm{H} 6.0=6.1$, about one-half was globulin, about a quarter $\alpha^{-}$, and a quarter $\beta$-globuli

*The term "euglobulin " has been used promiscuous $\mathbb{\mathbb { D }}$ to mean the fraction that is insoluble at low salt concentra tions, the fraction precipitated by $\frac{1}{3}$ saturation wit ammonium sulphate, and that precipitated by $13.5 \%$ sodium sulphate. If the term is used the precise meaning should be specified. 
TABLE II

PARTITION OF SERUM PROTEINS (g./100 ml.) BY HOWE'S METHOD (GUTMAN ET AL., 1941)

\begin{tabular}{|c|c|c|c|c|c|c|}
\hline & \multirow{2}{*}{$\begin{array}{c}\text { Total } \\
\text { Protein }\end{array}$} & \multirow{2}{*}{ Albumin } & \multicolumn{4}{|c|}{ Globulin } \\
\hline & & & $\mathrm{Eu}-$ & Pseudo-I & Pseudo-II & Total \\
\hline $\begin{array}{c}\text { Mean } \\
\text { Standard Deviation }\end{array}$ & $\begin{array}{l}7.2 \\
0.35\end{array}$ & $\begin{array}{l}5.2 \\
0.25\end{array}$ & $\begin{array}{l}0.2 \\
0.11\end{array}$ & $\begin{array}{l}1.3 \\
0.23\end{array}$ & $\begin{array}{l}0.5 \\
0.16\end{array}$ & $\begin{array}{l}2.0 \\
0.27\end{array}$ \\
\hline Range & 6.5 to 7.9 & 4.7 to 5.7 & $\left\{\begin{array}{c}\text { under } \\
0.1 \text { to } 0.4\end{array}\right\}$ & 0.8 to 1.9 & 0.2 to 0.8 & 1.3 to 2.4 \\
\hline
\end{tabular}

Quantitative Methods. - The ratio of albumin to globulin found by salt fractionation, by Howe's method, for example, is higher than that calculated from the electrophoretic patterns. Thus Dole and Braun (1944) found that the ratios measured electrophoretically were roughly two-thirds of the ratios found by Howe's method. This is due to two causes. First, the amount of globulin that is not precipitated by the critical concentration of salt $(21.5 \%$ sodium sulphate in Howe's method) is more than the amount of albumin that is precipitated at this concentration. Second, the estimates of protein in the salt fractions are actual estimates of the amounts of nitrogen in these fractions: the estimates of the electrophoretic fractions, calculated from the areas of the peaks, include lipids which contain little nitrogen. As the globulins contain more lipid than the albumin the ratio of globulin to albumin calculated from the areas under the peaks is higher than the ratio based on nitrogen contents. When the electrophoresis is run at $p \mathrm{H}$ about 7.8 the $a_{2}$-globulin is included in the albumin, and the ratio of albumin to globulin then agrees more closely with that found by the usual salt-fractionation methods.

Attempts have been made to devise simple precipitation methods by which the relative concentrations of the fractions separated will agree better with those estimated by electrophoresis. Milne (1947) and Kibrick and Blonstein (1948) recommend the use of $15.75,19.90$, and $27.20 \%$ solutions of sodium sulphate for precipitation. Twenty volumes of these solutions are added to one volume of serum, and the final concentrations are then 15,19 , and $26 \%$. The amount of protein precipitated by $15 \%$ was called $\gamma$-globulin ; the difference between the amounts precipitated by 19 and $15 \%, \beta$-globulin; the difference between the amounts precipitated by 26 and $19 \%$, a-globulin ; and the protein left in solution, albumin.

The amount of $\gamma$-globulin estimated in this way in 14 sera agreed well with the amount of electrophoretic $\gamma$-globulin. In only two sera was the difference greater than $0.2 \mathrm{~g} . / 100 \mathrm{ml}$. Out of 10 sera the estimates of $\beta$-globulin by the two methods differed by less than $0.2 \mathrm{~g} . / 100 \mathrm{ml}$. in all but one serum, and the estimates of $a$-globulin by less than $0.3 \mathrm{~g}$. $/ 100 \mathrm{ml}$. in all but one. The authors do not mention whether the electrophoresis was run at $p \mathrm{H} 7.8$ or 8.6 , but the amounts of electrophoretic a-globulin given are those that would be expected if it included both $a_{1}$ - and $a_{2}$ globulin.

Pillemer and Hutchinson (1945) introduced a method of precipitation with methyl alcohol in the cold. They found that the amount of protein precipitated agreed well with the amount of globulin estimated by electrophoresis. However, Nitshe and Cohen (1947), using this method, found in 23 normal sera a ratio of albumin to globulin (2.25), which is much higher than any found by electrophoresis. Martin and Morris (1949) have confirmed that the albumin/globulin ratio found by precipitation with $26 \%$ sodium sulphate and by the methyl alcohol method agree with that found by electrophoresis at

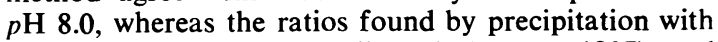
sodium sulphite (Campbell and Hanna, 1937) and magnesium sulphate (Popjak and McCarthy, 1946) did not.

Low-Temperature-Low-Salt-Low-Dielectric-Constant Fractionation.-The separation of proteins in this

TABLE III

DISTRIBUTION OF ELECTROPHORETIC FRACTIONS (g./100 ml. OF ORIGINAL PLASMA) SEPARATED BY THE LOW-TEMPERATURE-LOW-SALT-LOW-DIELECTRIC-CONSTANT-FRACTIONATION METHOD

\begin{tabular}{|c|c|c|c|c|c|c|c|c|c|}
\hline \multirow{2}{*}{ Fraction } & \multirow{2}{*}{$\begin{array}{c}\text { Ethanol } \\
\text { Concentration } \\
(\%)\end{array}$} & \multirow{2}{*}{$p \mathrm{H}$} & \multirow{2}{*}{ Ionic Strength } & \multirow{2}{*}{$\begin{array}{c}\text { Temperature } \\
\left({ }^{\circ} \mathrm{C}\right)\end{array}$} & \multicolumn{5}{|c|}{ Globulin } \\
\hline & & & & & Albumin & $x$ & $\beta$ & $\gamma$ & Fibrinogen \\
\hline $\begin{array}{c}\text { II } \underset{\text { and III }}{\text { IV } \pm 1} \\
\text { IV } 4 \\
\text { V }\end{array}$ & $\begin{array}{l}8-10 \\
25 \\
18 \\
40 \\
40\end{array}$ & $\begin{array}{l}7.2 \\
6.8 \\
5.2 \\
5.8 \\
4.8\end{array}$ & $\begin{array}{l}0.14 \\
0.09 \\
0.09 \\
0.09 \\
0.11\end{array}$ & $\begin{array}{l}-3 \\
-5 \\
-5 \\
-5 \\
-5\end{array}$ & $\begin{array}{l}0.2 \\
0.8 \\
0 \\
0.9 \\
29.9\end{array}$ & $\begin{array}{l}0.3 \\
1.1 \\
4.5 \\
2.7 \\
1.3\end{array}$ & $\begin{array}{l}0.5 \\
9.1 \\
0.5 \\
2.2 \\
0.3\end{array}$ & $\begin{array}{l}0.3 \\
7.0 \\
0.1 \\
0 \\
0\end{array}$ & $\begin{array}{l}2.1 \\
1.9 \\
0 \\
0 \\
0\end{array}$ \\
\hline
\end{tabular}




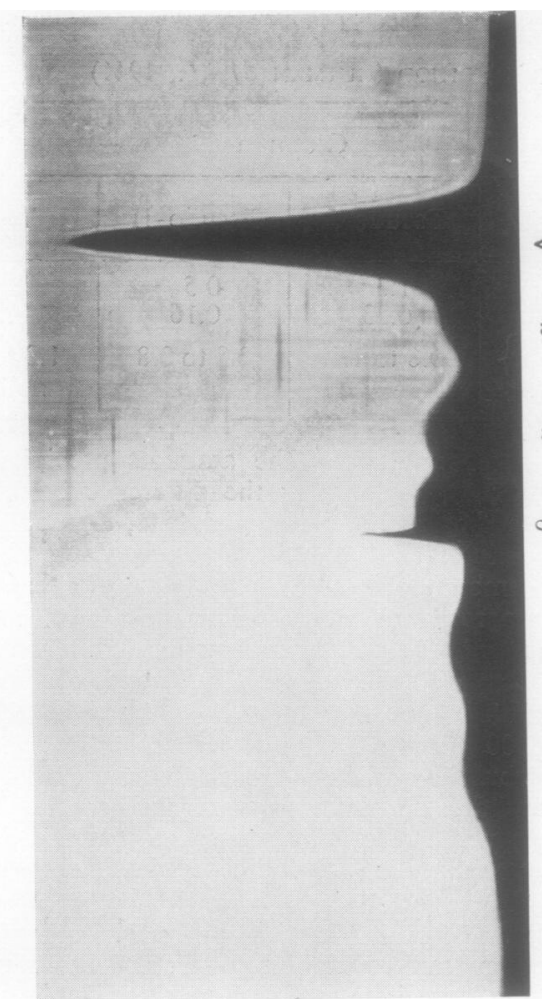

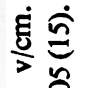

a है

त

ํㅗㄹ

$<8$

$8 \frac{1}{2}$

ช $\dot{0} \ddot{\dot{\theta}}$

동

氙

을 음

$\stackrel{\infty}{0} \ddot{=}$

퐁

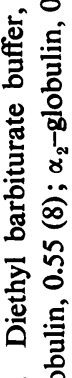

离产造

तर

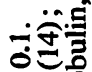

ธ8ㅎํ

象

ए.

<

ํำ

18

i.

हैं क्ञ

ह

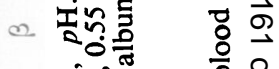

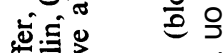

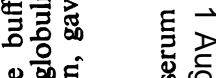

पํำ

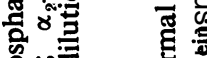

落

है으

हं子

हீॅ

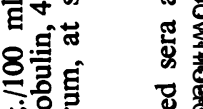

so․․에

궁

ㅇ.

웡

ह1

ชี่์

อำํํำ

in

敋寀

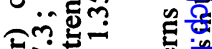

ơं क्

용

อี.

웅응

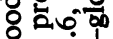

त्र $\sigma^{\infty}$

. 월

를

어으 응

ํ.

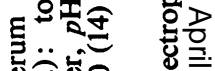

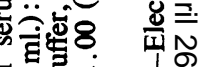

สำ-

ก

हैछ

일 $\quad$ in

ऽ류용

茫

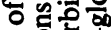

아

ह

壱 8

.

$<\quad$ 氙 :

․ํำ

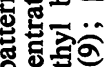

응흐를

응응

ㄸำ

m 
process, developed by Cohn and his colleagues, depends on the fact that small variations of the ionic strength or dielectric constant of solutions may have a great effect on the solubility of protein molecules; this effect depends on the electric configuration which may be highly characteristic of certain molecules. The dielectric constant is lowered by the addition of ethyl alcohol. The five variables-namely, ionic strength, concentration of protein, $p \mathrm{H}$, temperature, and dielectric constant-can be varied independently. The main fractions obtained are given in Table III. Fractions II+III and IV -4 are further broken down into sub-fractions. A variety of proteins that appear homogeneous have been isolated and proteins that have physiological activity have been allccated to the various fractions (Tables VI and VIII). As appears from Table III, this method does not separate proteins-according to their mobilities, but various refined proteins have thus been prepared for therapeusis. These include albumin, which contains little salt ; globulin, containing antibodies to measles, whooping-cough, diphtheria, scarlet fever, etc.; fibrinogen for making fibrin foam, a haemostatic; and fibrin film, an absorbable membrane. A full description of the method and the theory on which it is based is given by Edsall (1947).

\section{Normal Concentrations of Serum Proteins}

Total Protein.-Estimates of the normal concentrations of proteins in serum differ widely. The means reported by some authors are below the lower limits reported by others. This may be accounted for, in part, by a difference of activity and of posture of the subjects. Thus Perera and Berliner (1943) found that the total protein in the serum of normal ambulant subjects was about $0.8 \mathrm{~g} . / 100 \mathrm{ml}$. more than after they had been in bed for some hours. During recent years more attention has been paid to the technique for estimating nitrogen, and most estimates of concentrations in the serum of healthy persons who are up and about approximate to those of Gutman et al. (1941) given in Table II. The effect of posture should be born in mind when the concentrations in the serum of bedridden patients are considered.

The proteins of serum are considered in this discussion, but proteins are often estimated in plasma. If oxalate is used as an anticoagulant, water diffuses out of the erythrocytes to compensate for the increased concentration of salt in the plasma. This water dilutes the plasma slightly, and consequently the concentration of protein found in oxalated plasma is usually no higher than that found in serum, although the plasma contains about $0.3 \mathrm{~g} . / 100 \mathrm{ml}$. of fibrinogen whereas the serum contains none.
It should be noted that these concentrations are calculated by multiplying the protein-nitrogen by the conversion factor $6.25 .^{*}$ To get the concentration of protein-lipid-carbohydrate complex the average factor for use with normal serum should be 6.73 (Armstrong et al., 1947), but the use of this factor is undesirable as the amount of lipid varies.

Electrophoretic Fractions.-Examples of the proportions and amounts of the fractions separated by electrophoresis are given in Table IV. In the estimates made at $p \mathrm{H} 7.8$ the albumin includes $\alpha_{1}$-globulin. Dole's subjects were healthy young male adults, but Armstrong's samples were drawn from pools of plasma from blood donors. The concentrations of the globulin fractions reported by Dole and by Lewis and McCullagh are lower than those reported by Seibert and colleagues. The mean concentration of $\gamma$-globulin according to Dole differs from the mean of Seibert et al. by almost two standard deviations. This difference must be borne in mind when the concentrations of the globulin fractions in abnormal sera are considered.

Serum Proteins in Pregnancy and Infancy.After about the twenty-second week of pregnancy the serum protein falls by an average amount of 0.8 g. $/ 100 \mathrm{ml}$. (Plass and Matthew, 1926 ; Oberst and Plass, 1932, 1936 ; Hoch and Marrack, 1948). The albumin alone is reduced, and this reduction runs parallel to the reduction of the concentration of haemoglobin in the blood occurring at the same time; both are attributed to increase of the blood volume. After delivery the albumin rises.

The serum proteins of babies at birth are low and variable; mean concentrations range from 5.11 (Rapoport et al., 1943) to 5.52 (Darrow and Cary, 1933). Lower values are found in the serum of premature babies. The concentration rises slowly during the first six months (Hickmans et al., 1943), and adult levels are reached by the third year (Trevorrow et al., 1941-2).

Longsworth et al. (1945) reported electrophoretic analyses of the plasma or serum of foetal blood drawn from the umbilical cord and of maternal blood taken one hour after delivery. In the maternal plasma or serum the average concentration of albumin was low $(3.56 \mathrm{~g} . / 100 \mathrm{ml}$.) and the concentration of $\beta$-globulin raised (1.62 g./ $100 \mathrm{ml}$.). In foetal plasma or serum the albumin (3.82 g./

\footnotetext{
*Various methods, such as the biuret and tyrosine methods are standardized by nitrogen estimations.
} 
TABLE IV

RELATIVE PROPORTIONS AND ABSOEUTE CONCENTRATIONS (g./100 ml.) OF ELECTROPHORETIC FRACTIONS IN NORMAL PLASMA AND SERUM

\begin{tabular}{|c|c|c|c|c|c|c|c|c|c|c|c|c|c|c|c|}
\hline \multirow{4}{*}{$\begin{array}{l}\text { Armstrong et al., } \\
(1947) \text {. Mean of } 20 \\
\text { pools of plasma... } \\
\text { Dole (1944). Plasma } \\
\text { of } 15 \text { young male } \\
\text { adults. } \\
\text { Mean } \\
\text { S.D. }\end{array}$} & \multirow{2}{*}{$p \mathrm{H}$} & \multicolumn{6}{|c|}{ Percentage of Total Protein } & \multicolumn{6}{|c|}{ Concentration (g./100 ml.) } & \multirow{2}{*}{$\begin{array}{c}\text { Total } \\
\text { Protein } \\
\text { (g./100 } \\
\text { ml.) }\end{array}$} & \multirow{2}{*}{$\mathbf{A} / \mathbf{G}$} \\
\hline & & Alb. & $\alpha_{1}$ & $\alpha_{2}$ & $\alpha$ & $\varphi$ & $\gamma$ & Alb. & $\alpha_{1}$ & $\alpha_{2}$ & $\beta$ & $\varphi$ & $\gamma$ & & \\
\hline & 8.6 & 55.2 & 5.3 & 8.7 & 13.4 & 6.5 & 11.0 & & & & & & & & \\
\hline & 8.6 & $\begin{array}{r}60.3 \\
2.8\end{array}$ & $\begin{array}{l}4.6 \\
0.7\end{array}$ & $\begin{array}{l}7.2 \\
1.3\end{array}$ & $\begin{array}{r}12.1 \\
1.9\end{array}$ & $\begin{array}{l}5.1 \\
0.6\end{array}$ & $\begin{array}{r}11.0 \\
2.5\end{array}$ & $\begin{array}{l}4.04 \\
0.27\end{array}$ & $\left|\begin{array}{l}0.31 \\
0.051\end{array}\right|$ & \begin{tabular}{|l|l}
0.48 \\
0.083
\end{tabular} & $\begin{array}{l}0.81 \\
0.126\end{array}$ & $\begin{array}{l}0.34 \\
0.059\end{array}$ & \begin{tabular}{|l|}
0.74 \\
0.151
\end{tabular} & $6.7^{*}$ & $\begin{array}{l}1.53 \\
0.181\end{array}$ \\
\hline $\begin{array}{l}\text { adults. Mean } \\
\text { S.D. } \\
\text { Range }\end{array}$ & 8.5 & \begin{tabular}{|r|}
53.3 \\
2.6 \\
47.6 \\
59.2
\end{tabular} & $\begin{array}{r}8.0 \\
1.35 \\
5.3 \\
11.5\end{array}$ & $\begin{array}{l}10.4 \\
1.38 \\
7.7- \\
12.9\end{array}$ & \begin{tabular}{|c|}
13.8 \\
1.89 \\
7.9 \\
11.6
\end{tabular} & & $\begin{array}{r}14.2 \\
2.68 \\
8.7 \\
19.7\end{array}$ & $\begin{array}{l}3.88 \\
0.23 \\
3.4 \\
4.3\end{array}$ & $\begin{array}{l}0.58 \\
0.10 \\
0.38 \\
0.87\end{array}$ & $\begin{array}{l}0.76 \\
0.10 \\
0.57 \\
0.94\end{array}$ & $\begin{array}{l}0.01 \\
0.14 \\
0.73 \\
1.38\end{array}$ & & $\begin{array}{l}1.05 \\
0.22 \\
0.59 \\
1.46\end{array}$ & $\begin{array}{l}7.29 \dagger \\
0.35 \\
6.3- \\
8.2\end{array}$ & $\begin{array}{l}1.15 \\
0.12 \\
0.91- \\
1.45\end{array}$ \\
\hline $\begin{array}{l}\text { Moore } \text { et al. }(1941) \\
\text { Plasma of } 25 \text { normal } \\
\text { adults }\end{array}$ & 7.8 & 62.5 & & 7.5 & 13.1 & 5.0 & 11.9 & & & & & & & & \\
\hline $\begin{array}{l}\text { Lewis and McCullagh } \\
\text { (1944). Plasma of } 21 \\
\text { normal adults. } \\
\text { Mean } \\
\text { Range }\end{array}$ & 7.8 & $\begin{array}{l}62.7 \\
60.1- \\
67.2\end{array}$ & & $\begin{array}{l}7.2 \\
6.0 \\
8.7\end{array}$ & $\begin{array}{l}13.1 \\
11.0 \\
15.9\end{array}$ & $\begin{array}{l}5.4 \\
2.8 \\
7.2\end{array}$ & $\begin{array}{r}11.7 \\
8.6 \\
14.8\end{array}$ & $\mid \begin{array}{l}4.09 \\
3.72- \\
5.11\end{array}$ & & $\begin{array}{l}0.47 \\
0.39 \\
0.66\end{array}$ & $\begin{array}{l}0.81 \\
0.65 \\
1.07\end{array}$ & & $\begin{array}{l}0.77 \\
0.55 \\
0.91\end{array}$ & $\begin{array}{l}6.51^{*} \\
5.94- \\
7.82\end{array}$ & \\
\hline
\end{tabular}

$100 \mathrm{ml}$.) and $\gamma$-globulin $(0.97 \mathrm{~g} . / 100 \mathrm{ml}$. $)$ were higher and other globulin fractions lower than in the maternal samples.

The sera of new-born calves, lambs, and foals contain very little $\gamma$-globulin. The colostrum contains a globulin which resembles the $\gamma$-globulin of serum (Smith, 1946). After the new-born animals have ingested colostrum, $\gamma$-globulin appears in their serum, but ingestion of colostrum after the calves have reached 24 hours of age does not lead to an increase of $\gamma$-globulin (Hansen and Phillips, 1947). It seems that during the first day of life this globuin is absorbed without being split up by digestive enzymes.

Pedersen (1944) found that about $20 \%$ of the total protein and 50 to $80 \%$ of the globulin in the serum of newborn calves is a new protein which he called "fetuin." The molecular weight of this protein is 51,000 , which is less than that of albumin. The serum of foetal foals and lambs also contains fetuin.

\section{Composition, Physical, and Physiological Properties}

Composition.-This is discussed under the headings amino acids, lipids, and carbohydrate.

Amino Acids.-Complete estimates of the amino acids of the albumin, $\alpha-, \beta-$, and $\frac{\varnothing}{\varnothing}$ $\gamma$-globulin, and fibrinogen of human serum $\varrho$ have been compiled by Edsall (1947) from 0 the work of Brand, Kassel, and Saidel (1944), 3 Brand (1946), and Shemin (1945). The chief points of interest are the very low content of tryptophane and the relatively low content of 옹 glycine in albumin. The contents of various groups of amino acids run in the following 3 . orders :

Basic: $\quad$ Albumin $>a$-globulin $>\beta$-globulin $>\gamma$-globulin.

Di-carboxylic: $a$-globulin $>$ albumin $>\beta$-globulin $>\gamma$-globulin.

Hydroxy: $\quad$ Albumin $<a$-globulin $<\beta$-globulin $<\gamma$-globulin.

Lipids.-Blix, Tiselius, and Svensson (1941) N found that the $\alpha$ - and $\beta$-globulin of normal $N$ human serum contain considerable quantities of cholesterol and phospholipids (Table V). Reckoning the phospholipid as lecithin the total amounts (averages of three normal sera) in these fractions were 11.7 and $18.7 \%$. Edsall (1947) considers that the amounts of cholesterol found in albumin and $\gamma$-globulin indicate that these fractions were impure, as Cohn, Strong et al. (1946) found under $0.04 \%$ and $0.06 \%$ of cholesterol in purified albumin and $\gamma$-globulin. 
TABLE V

LIPID AND CARBOHYDRATES, AS MANNOSE (g. per $100 \mathrm{~g}$.), IN ELECTROPHORETIC FRACTIONS OF HUMAN SERUM*

\begin{tabular}{c|c|c|c|c|c|c}
\hline & \multicolumn{3}{|c|}{ Normal } & \multicolumn{3}{|c}{ Pneumonia } \\
\cline { 2 - 6 } $\begin{array}{c}\text { Electrophoretic } \\
\text { Fractions }\end{array}$ & Cholesterol & $\begin{array}{c}\text { Lipid- } \\
\text { Phosphorus }\end{array}$ & Carbohydrate & Cholesterol & $\begin{array}{c}\text { Lipid- } \\
\text { Phosphorus }\end{array}$ & Carbohydrate \\
\hline Albumin & 1.07 & 0.09 & 1.15 & 0.71 & 0.02 & 5.8 \\
$\alpha$-Globulin & 4.45 & 0.29 & 6.0 & 0.42 & 0.21 & 9.9 \\
$\beta-$ Globulin & 8.67 & 0.40 & 6.2 & 0.56 & 1.5 \\
$\gamma$-Globulin & 0.41 & 0.04 & 3.0 & 0.28 & 0.12 & 3.7 \\
\hline
\end{tabular}

- Adapted from Blix, Tiselius, and Svensson (1941).

By the special methods developed by the Harvard school two lipoproteins have been isolated from human serum (Table VI). One, with the mobility of $\alpha$-globulin, contains $10 \%$ of nitrogen, $16 \%$ of cholesterol, and $35 \%$ of total lipid ; the other, with the mobility of $\beta$-globulin contains only $4 \%$ of nitrogen, $35 \%$ of cholesterol, and $75 \%$ of total lipid. The conversion factors, by which the nitrogen in these two lipoproteins should be multiplied to obtain the weight of lipoprotein, are 10 and 25.

Carbohydrate.-Table V shows that there is more carbohydrate in the $\alpha$ - and $\beta$-globulin of human serum than in the albumin and $\gamma$-globulin. There is some confusion about the amounts of carbohydrate in albumin and other components that are precipitated by the higher concentrations of ammonium and sodium sulphate. Hewitt (1937) prepared a fraction from horse serum which he called " globoglycoid.". Rimington and Van den Ende (1940) consider that this is a complex of albumin and globulin. They prepared two albumins from ox serum, both of which contained very little carbohydrate; one crystallized in hexagonal plates and the other in needles. McMeekin's (1940) horse serum albumin that contained 5.5\% of carbohydrate crystallized in hexagonal discs; his carbohydrate-free albumin crystallized in rods ; the two albumins had the same molecular weights.

Besides true albumin the filtrates obtained after precipitation of globulin contain two proteins, seroglycoid and seromucoid, which contain large amounts of carbohydrate. Hewitt's (1937) seroglycoid from human serum contains $8.9 \%$ and seromucoid $25 \%$ of carbohydrate. Both are not coagulated by heat, but seroglycoid is carried down with the coagulum when it is heated with coagulable proteins. Hewitt (1938) believes that the amount of seroglycoid in human serum is of the order of $0.4 \mathrm{~g} . / 100 \mathrm{ml}$. These carbohydraterich proteins have received little attention in the most recent investigations. An $\alpha_{2}$-globulin, which contains $4.3 \%$ of carbohydrate and has the solubility of albumin, has been isolated (Surgenor, Strong et al., 1948).

Molecular Weights. - When a solution of a protein is spun in an ultracentrifuge, a boundary zone, above which the solution is free from this protein, travels down the column of solution. If solutions of proteins which have different sedimentation rates are spun, the boundaries can be observed as peaks, as in electrophoresis; the area under a peak is proportional to the concentration of the corresponding protein. Sedimentation constants, calculated from the distance that the boundary sinks in a given time, are reckoned in Svedberg units (S). The sedimentation constants of molecules depend on their weights, shapes, and densities. Other things being equal the sedimentation rate rises with the molecular weight: a spherical molecule has a higher sedimentation rate than a flat or elongated molecule. The molecular weight of a protein can be calculated from the sedimentation rate, diffusion constant, and partial specific volume; also from the distribution of the molecules, when they have attained equilibrium in a gravitational field, and from the osmotic pressure. If it is assumed that the molecules have a certain shape the ratio of the long to the short axis can be calculated. In Table VI it is assumed that the molecules, other than the $\beta$-lipoprotein, are prolate spheroids (that is, cigar-shaped) and that the $\beta$-lipoprotein is approximately spherical.

The ultracentrifuge has been used mainly to measure the sedimentation constants of isolated proteins. A difficulty arises, however, in the interpretation of the sedimentation patterns found with whole human serum, but not with the serum of other animals. Four peaks are found (Pedersen, 1945). One small peak corresponds to a heavy fraction with a sedimentation constant between 
TABLE VI

PHYSICAL PROPERTIES OF FRACTIONS ISOLATED FROM HUMAN SERUM (ONCLEY, SCATCHARD, AND BROWN, 1947)

\begin{tabular}{|c|c|c|c|c|}
\hline Fraction & $\begin{array}{l}\text { Sedimentation } \\
\text { Constant }\end{array}$ & $\begin{array}{l}\text { Partial Specific } \\
\text { Volume }\end{array}$ & $\begin{array}{l}\text { Molecular } \\
\text { Weight }\end{array}$ & $\begin{array}{c}\text { Calculated } \\
\text { Dimensions, A }\end{array}$ \\
\hline 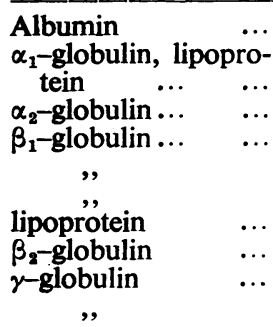 & $\begin{array}{c}4.6 \\
5.0 \\
9 \\
5.5 \\
7 \\
20 \\
2.9 \\
7 \\
7.2 \\
10\end{array}$ & $\begin{array}{l}0.733 \\
0.841 \\
0.693 \\
0.725 \\
0.74 \\
0.74 \\
0.950 \\
0.739\end{array}$ & $\begin{array}{c}69,000 \\
200,000 \\
(300,000) \\
90,000 \\
(150,000) \\
(500,000 \text { to } 1,000,000) \\
1,300,000 \\
(150,000) \\
156,000 \\
(300,000)\end{array}$ & $\begin{array}{l}150 \times 38 \\
300 \times 50 \\
190 \times 37 \\
185 \times 185 \\
235 \times 44\end{array}$ \\
\hline
\end{tabular}

$17 \mathrm{~S}$ and $20 \mathrm{~S}$. A larger peak corresponds to the bulk of the globulin with a sedimentation constant of about $7 \mathrm{~S}$. A third peak corresponds to the albumin, and a fourth, that of the "x-component,' merges with the albumin peak. As the concentration of the serum rises the proportion of the protein in the form of the $\mathrm{x}$-component rises. The reason for the relatively slow rate of sedimentation of this component is not the relative smallness of its molecules, but their low density, which is due to a high concentration of lipid (Pedersen, 1945). Pedersen considers that the x-protein is a complex formed by albumin, globulin, and lipid. It disappears when the lecithin of serum is broken down by the lecithinase of $\mathrm{Cl}$. Welchii (Peterman, 1946). The lipoproteins of Table VI account for only about $5 \%$ of the total protein of serum, whereas the $x$-protein may amount to $50 \%$ or more of the total protein in undiluted sera. Blix and Pedersen (1947) think that the $\mathrm{X}$-protein " must in the main be composed of other fractions than the $\beta$-lipoprotein." The question then arises as to whether the fractions, isolated even by such gentle methods as electrophoresis, are actually separate in serum. The globulin fractions with the sedimentation constants 5.0, 5.5, 9, and $10 \mathrm{~S}$ cannot be detected in the sedimentation patterns of whole serum.

\section{Immunology}

Antibodies.-Studies of the mobilities and molecular weights of antibodies are reviewed by Kabat (1943). In the rabbit 'sera that have been studied antibodies have been found in the $\gamma$-globulin and have molecular weights of the same order (about 160,000 ) as that of the bulk of the $\gamma$-globulin. In horse sera, antibodies may have the mobility of $\gamma$-globulin, or mobilities ranging from that of the faster $\gamma$-globulin $\left(\gamma_{1}\right.$-globulin) to that of the slower $\beta$-globulin $\left(\beta_{2}\right.$-globulin); the 은 T-fraction (Van der Scheer, Wyckoff and Clarke, $\vec{P}$ 1940) has a mobility between those of $\beta$ - and $\gamma$-globulin. The molecular weights of the horseserum antibodies to protein antigens are of the $\stackrel{\infty}{?}$ same order as that of the bulk of the $\gamma$-globulin. $\vec{\varphi}$ Antibodies to polysaccharides (such as those of 0 pneumococci) may have much higher molecular $\square$ weights of the order of 900,000 or molecular weights intermediate between this and that of normal $\gamma$-globulin.

The fractions II-1, 2, and 3 of human serum $\stackrel{\circ}{\varnothing}$ separated by Cohn's methods, of which $98 \%$ is $\gamma$-globulin by electrophoretic standards, contain a 응 large number of antibodies effective in diphtheria, $\frac{3}{\sqrt{3}}$ influenza, mumps, whooping cough, scarlet fever, poliomyelitis, lymphocytic choriomeningitis, and against certain streptococci and vaccinia. Typhoid $\frac{8}{8}$ $\mathrm{H}$-agglutinin is found mainly in fractions II-1, 2, and 3 ; typhoid $\mathrm{O}$-agglutinin and the isohaemagglutinins in fraction III-1 (Edsall, 1947). 응 According to Deutsch et al. (1946) the isohaem-

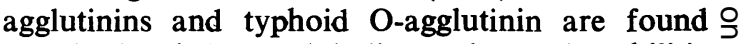
mainly in their $\gamma_{1}$-globulin. The anti-syphilitic $D$ antibody also has a mobility between those of $\beta$ - 을. and $\gamma$-globulin according to Davies et al. (1945); N Erickson et al. (1947) also placed most of the activity in the faster $\gamma$-globulin, but found some $\tilde{N}$ activity in the slower $\beta$-globulin.

In the sera of human beings and monkeys antibodies to pneumococcal polysaccharides have 0 molecular weights of about 160,000. However, $\overparen{\varnothing}$ haemagglutinins in rabbit sera (Paič, 1939) and $\stackrel{\mathscr{P}}{+}$ the isohaemagglutinins of human sera (Pedersen, $\square$ 1946) have molecular weights of the order of $1,000,000$. The anti-syphilitic antibody, extracted $\stackrel{\mathbb{O}}{\square}$ from the floccules formed with Kahn antigen, $\stackrel{\mathbb{Q}}{\varrho}$ had two components with sedimentation constants corresponding to molecular weights of 
about $1,000,000$ and 160,000 ; there was more of the lighter component, but the heavier was more active serologically (Davis et al., 1945).

As already noted the concentration of $\gamma$-globulin in the serum of a new-born baby is rather higher than that in the mother's serum. The baby's serum also contains any antibodies present in the mother's serum in about the same concentration. On the other hand no antibodies can be detected in the sera, which contain little $\gamma$-globulin, of newborn calves, lambs, and foals.

Generally it may be said that antibodies in human serum are found in the $\gamma$-globulin or in a fraction with a mobility between those of $\beta$ - and $\gamma$-globulin, and that the antibodies to all protein antigens, as far as is known, have molecular weights of the same order as that of the greater part of normal serum globulin. Boyd and Bernard (1937) suggested that all $\gamma$-globulin may be antibody of some sort. Kabat (1943) points out that the amount of antibody in the serum of non-immune persons is small. The largest amount, reported in a human being who had recently recovered from pneumonia, was about $1 \mathrm{mg}$. of antibody protein/ ml. (Kabat, 1939) ; no antibody could be detected in the serum of the same person several months later. Absorption of antibodies with homologous streptococci from the serum of patients with rheumatic fever, when the antistreptolysin $O$ titre was raised, did not change the relative concentrations of the $\gamma$-globulin or other serum fractions significantly (Dole, Watson, and Rothbard, 1945). When animals are immunized the serum globulin increases, but by no means all this increase is active antibody (Marrack, 1938). It is probable that a large proportion of the $8 \mathrm{mg}$. or so of $\gamma$-globulin in $1 \mathrm{ml}$. of human serum is such inert globulin, which may be called " reaction" globulin.

Serum Proteins as Antigens.- -Rimington and van den Ende (1940), using the guinea-pig uterus technique, found no antigenic difference between the two forms of albumin that they prepared from ox serum and that the albumin, seroglycoid and seromucoid reacted as distinct antigens. The albumin of human serum does not cross-react with other serum proteins. Chow (1947) has used antiserum for estimating albumin in serum and found concentrations which agreed with those obtained by electrophoresis at $p \mathbf{H} 8.4$. The immunology of the seroglycoid and seromucoid of human serum has not been studied.

The question arises whether the various components of any one of the three fractions, $\alpha-, \beta-$, and $\gamma$-globulin of human serum, are antigenically similar, although they differ in other properties, and whether proteins, similar antigenically, may occur in different electrophoretic fractions.

The immunological method recently introduced by Oudin (1946) shows that horse serum contains at least eight distinct antigens; it is not possible to recognize which are the antigens that are detected. It is possible that two of these are seroglycoid and seromucoid. This would leave albumin and five globulin antigens. In horse serum antigenic differences were found between the high-molecular weight antibodies to bacterial polysaccharides, diphtheria antitoxin, and a $\gamma$ globulin of high molecular weight prepared from normal horse serum, all of which had the mobility of $\gamma$-globulin; $\beta$-globulin formed some precipitate with an antiserum to high-molecularweight antibody (Treffers et al., 1941, 1942). On the other hand, in rabbit serum, which resembles human serum more than horse serum does, no antigenic differences were detected between normal $\gamma$-globulin, antibody to egg-albumin, and antibodies to bacterial polysaccharides (Treffers and Heidelberger, 1941).

Kendall (1937) prepared a fraction of human globulin by precipitation methods, and called it " $\alpha$-globulin," but identified with the $\gamma$-globulin of Tiselius. We have confirmed by electrophoresis in the Tiselius apparatus (Marrack, Johns, and Hoch, 1949) that this " $\alpha$-globulin" is mainly $\gamma$ globulin ; preparations usually contain less than $6 \%$ of-faster fractions. Kendall prepared antiserum to his " $\alpha$-globulin." After absorbing this antiserum with other globulin fractions he used it for estimating the amount of this fraction in serum by the quantitative precipitin method. The concentrations he found were about double the amounts of $\gamma$-globulin found by electrophoresis. Jager et al. (1948) made antisera by immunizing with $\gamma$-globulin prepared by Cohn's method and found similar high concentrations. However, they did not absorb their antisera with other globulin fractions. On the other hand, Kibrick and Blonstein (1948) immunized rabbits with $\gamma$-globulin, free from other electrophoretic components; the antisera were absorbed with albumin and with $\beta$ - and $\alpha$-globulin. The estimates of $\gamma$-globulin in human serum made with these antisera agreed with the estimates made by their method of fractionation with sodium sulphate, and these, again, agreed with the estimates by electrophoresis.

By Kendall's method a small fraction only of the total $\gamma$-globulin of serum is recovered as Kendall's “ $\alpha$-globulin." We have found (Marrack, Johns, and Hoch, 1949) that $\gamma$-globulin, separated 
by electrophoresis, and Kendall's" "a-globulin" gave identical precipitation curves with some antisera to Kendall's " $\alpha$-globulin." Estimates, with these antisera, of the $\gamma$-globulin in normal human serum agreed with estimates made from the electrophoresis pattern. We, therefore, detected no antigenic difference between different fractions of the $\gamma$-globulin. However, estimates of $\gamma$-globulin in normal serum made with other antisera to Kendall's " $\alpha$-globulin" were considerably higher than those found by electrophoresis. The type of reaction suggested a cross-reaction between antibodies to $\gamma$-globulin and other globulin fractions rather than the presence in the antisera of antibodies to antigens other than $\gamma$-globulin. In view of Kendall's results and the cross-reaction which Treffers et al. (1942) found between horse $\beta$ - and $\gamma$-globulins we are doubtful whether $\beta$ - and $\gamma$ globulins can be regarded as antigenically completely distinct. On the other hand, the C-reactive protein, mentioned later, has the mobility of $\alpha$ globulin but is a distinct antigen. Members of the same electrophoretic fraction may therefore be antigenically different.

Complement.-Four components are recognized in complement. $C^{\prime} 1$ (mid-piece) is heat labile and al., 1941), and of the $C^{\prime} 1, C^{\prime} 2$, and $C^{\prime} 4$ of human 은 serum (Pillemer et al., 1943, Ecker et al., 1945). It appears that $C^{\prime} 2$ and $C^{\prime} 4$ form a complex in? guinea-pig serum, but not in human serum. If the electrophoretic fractions of guinea-pig serum are $\bar{\omega}$. analogous to those of human serum, the $C^{\prime} 1$ is a $\beta-\vec{\nabla}$ globulin and the $C^{\prime} 2-C^{\prime} 4$ complex an $\alpha$-globulin. The $C^{\prime} 1$ of human serum is a $\beta$-globulin, most of which has a sedimentation constant close to that $\vec{O}$ of the greater part of the serum globulin. About half the protein in the fraction that contained $C^{\prime} 2, \bar{\omega}$ isolated from human serum, was albumin; the slower component in the fraction had a mobility close to that of $\beta$-globulin.

The two fractions, $C^{\prime} 1$ and $C^{\prime} 2-C^{\prime} 4$, isolated ${ }_{\sigma}$ from guinea-pig serum together made up about ${ }_{\circ}^{-}$ $0.5 \mathrm{mg} . / \mathrm{ml}$. of serum; this is slightly more than the amount of protein that Heidelberger (1941) found was added to an immense precipitate when it absorbed complement from $1 \mathrm{ml}$. of guinea-pig

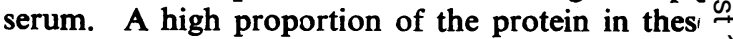
preparations from guinea-pig serum may, there- $\overrightarrow{0}$ fore, be active complement. The amount of com-co plement in human serum seems to be of the samed order. Properties of the components of human and guinea-pig complement are given in Table VII.

TABLE VII

PROPERTIES OF COMPONENTS OF COMPLEMENT

\begin{tabular}{|c|c|c|c|c|c|}
\hline \multicolumn{2}{|c|}{ Subject } & Resistance to Heat & $\begin{array}{l}\text { Mobility } \\
\text { (pH 7.7) }\end{array}$ & $\mathbf{S}$ & $\begin{array}{l}\text { Polysaccharide } \\
(\mathrm{g} . / 100 \mathrm{ml} .)\end{array}$ \\
\hline Guinea-pig & $\begin{array}{ll}C^{\prime} 1 & \ldots \\
C^{\prime} 2 & \ldots \\
C^{\prime} 4 & \ldots\end{array}$ & $\begin{array}{l}\text { Heat labile } \\
\text { Heat labile } \\
\text { Heat stable }\end{array}$ & $\begin{array}{l}2.9 \times 10^{-5} \\
4.2 \times 10^{-5}\end{array}$ & $\begin{array}{l}6.4 \\
\text { (major } \text { component) }\end{array}$ & $\begin{array}{r}2.7 \\
10.3\end{array}$ \\
\hline Human & $\begin{array}{l}C^{\prime} 1 \ldots \\
C^{\prime} 2 \ldots\end{array}$ & $\begin{array}{l}\text { Heat labile } \\
\text { Heat labile }\end{array}$ & $\begin{array}{l}2.9 \times 10^{-5} \\
2.6 \times 10^{-5}\end{array}$ & $\begin{array}{c}6.9 \\
\text { (major component) }\end{array}$ & 3 \\
\hline
\end{tabular}

insoluble in dilute salt solution (ionic strength below 0.1 ) at a $p H$ of about 5.2. $\mathrm{C}^{\prime} 2$ (end-piece), also heat labile, is distinguished from $\mathrm{C}^{\prime} 1$ as it does not become insoluble until the ionic strength is reduced to 0.01 . $C^{\prime} 3$ is relatively heat stable and can be removed from serum by adsorption on a polysaccharide prepared from yeast and by other means. $C^{\prime} 4$ is heat stable and is destroyed by mmonia and other amines that can combine with aldehyde groups. By fractional precipitation with ammonium sulphate and at a low $\mathrm{pH}$ and ionic strength, fractions have been isolated that contain a considerable proportion of the $\dot{C}^{\prime} 1$ and of the $C^{\prime} 2-C^{\prime} 4$ complex of guinea-pig serum (Pillemer et
Isolated $\gamma$-globulin is anti-complementary. The sera of a number of diseases (particularly malaria leprosy, and kala azar) give false positive reactions $\sim$ with the Wassermann and other tests for syphilis. N In most of these sera the concentration of $\gamma$-globulin is abnormally high (Cooper et al., 1946). Volkino et al. (1947) used the euglobulin, separated by dilution and acidification, for these tests. They claim? that crude albumin fractions from normal sera 0 inhibit false positives and do not inhibit true reactions. More recently they (Volkin et al., 1949) $\stackrel{\odot}{\circledR}$ have ascribed this inhibitory action to a phos. $\stackrel{\mathbb{Q}}{\mathcal{Q}}$ pholipid contained in the albumin fraction. Kabato (1946) regards with suspicion such methods of dis- 
tinguishing true from false reactions. He thinks that the procedures inhibit weak and do not inhibit strong reactions, so that the effect is merely to distinguish between strong and weak reactions. We may compare the degree of inhibition by haptenes of precipitate formation with homologous and heterologous antigens.

\section{Physiological Properties}

The distribution of physiologically active or important substances in the fractions separated by the low-temperature-low-ionic-strength-lowdielectric-constant method is given in Table VIII.

TABLE VIII

CONSTITUENTS AND PROPERTIES OF FRACTIONS SEPARATED BY LOW-TEMPERATURE-LOW-SALT-LOW-DIELECTRICCONSTANTT FRACTIONATION METHOD

\begin{tabular}{|c|c|c|}
\hline Fraction & $\begin{array}{l}\text { Constituent } \\
\text { Fractions }\end{array}$ & Properties \\
\hline I & $\begin{array}{l}\text { Fibrinogen } \\
\text { Antiphaemophilic } \\
\text { globulin }\end{array}$ & \\
\hline $\mathbf{I I}+\mathbf{I I I}$ & $\begin{array}{l}\gamma-\text { globulin } \\
\beta_{1}-\text { globulin, } \\
\text { including } \\
\text { lipo-protein } \\
\beta_{2} \text {-globulin }\end{array}$ & $\begin{array}{l}\text { Numerous antibodies } \\
\text { Carries cholesterol } \\
\text { phospholipids } \\
\text { vitamin A } \\
\text { carotenoids } \\
\text { steroid hormones } \\
\text { complement, midpiece } \\
\text { Prothrombin } \\
\text { Typhoid O-agglutinin } \\
\text { Iso-haemagglutinins }\end{array}$ \\
\hline IV -4 & $\begin{array}{l}\alpha_{1}-\text { globulin, } \\
\text { including } \\
\text { lipo-protein } \\
\beta_{1} \text {-globulin, } \\
\text { lipid free } \\
\alpha_{2} \text {-globulin } \\
\text { Albumin }\end{array}$ & $\begin{array}{l}\text { Carries cholesterol } \\
\text { phospholipids } \\
\quad \text { some steroids } \\
\text { Thyreotropic hormone } \\
\text { Idoprotein } \\
\text { Metal-combining protein } \\
\text { Carries bilirubin } \\
\text { Serum esterase } \\
\text { Hypertensinogen } \\
\text { Carries bilirubin }\end{array}$ \\
\hline & $\left|\alpha_{1}-g\right|$ & ," \\
\hline
\end{tabular}

The components with the lowest and highest mobilities serve familiar purposes. The $\gamma$-globulin contains antibodies. About $80 \%$ of the colloid osmotic pressure of serum is due to albumin, as it is present in the largest amount and has the lowest molecular weight. It is therefore essential for the maintenance of the plasma volume. Albumin has other special properties: it adsorbs a variety of substances which are little or not at all adsorbed by the globulin fractions other than $\alpha_{1}$ - and a carbohydrate-rich fraction of the $\alpha_{2}$-globulin. The most familiar of these is bilirubin. Some bilirubin is also carried by the $\alpha_{1}$ - and $\alpha_{2}$-globulin (Martin, 1949), and Cohn (1948) states that a protein in the $\alpha$-globulin fraction is the only one that carries the bilirubin that gives an indirect Van den Bergh reaction. A large number of other substances are adsorbed almost exclusively by serum albumin. For example, about $20 \%$ of phenol-sulphonephthalein in serum is free; the rest is adsorbed to albumin. The dye Evan's blue (T-1824) used for estimating plasma volume is carried by the albumin. This is the basis of the method of estimating Evan's blue devised by Morris (1944). Sulphanilamide and the sulphone drugs are adsorbed also. This adsorption must be taken into account in all comparisons of the concentration of a substance in the plasma with its rate of excretion in the urine. When the concentration of the albumin in the plasma is lower than normal, it may be expected that an abnormally high proportion of an adsorbable substance will be free.

A protein which has the special property of combining with metals has been crystallized (Koechlin, 1949). It has the mobility of $\beta_{1-}$ globulin, and contains $1.8 \%$ of carbohydrate. Its molecular weight is $90,000(\mathrm{~S}=5.0)$. The complex formed with iron has a salmon red colour (Schade, 1946) with maximum absorption at $465 \mathrm{~m} \mu$. The amount of complex formed is measured by the light absorption at this wave length. At a $p \mathrm{H}$ above $6.51 \mathrm{~g}$. of this protein will combine with $1.25 \mathrm{mg}$. of iron; this is two atoms of iron per molecule of protein (Surgenor, Koechlin, and Strong, 1949). The protein also combines with copper and with zinc. The maximum amount of copper, 2 atoms per molecule, is bound near $p \mathrm{H}$ 8.5. Below $p H 8$ iron will displace copper from the complex. Surgenor et al. estimate that $100 \mathrm{ml}$. of normal serum contains $0.24 \mathrm{~g}$. of this protein, capable of binding $0.3 \mathrm{mg}$. of iron. This estimate agrees with the maximum binding capacity $(0.315$ mg./ $100 \mathrm{ml}$.) found by Rath and Finch (1949).

The anti-haemophilic globulin can be precipitated from normal serum by dilution and acidification. The plasma of haemophilics clots in normal time when a solution of this globulin is added to it.

The $\alpha$ - and $\beta$-lipoproteins are particularly interesting. These proteins may serve merely as vehicles for lipids which are insoluble in water or they may have other functions.

\section{Serum Proteins in Disease}

Most of the changes of serum proteins, revealed by any method, except the immunological, are not specific. In most investigations the cases studied 
have not been followed through the course of the disease and the changes found in the serum proteins have not been correlated with the clinical condition or with ather chemical changes. Surveys of the investigations that have been made are apt to degenerate into a series of variations of ways of saying "M.N. (194x) found the relative concentration $\gamma$-globulin raised in P. disease."

Unfortunately many authors report the relative concentrations of electrophoretic components without mentioning the total concentration of protein. The albumin concentration falls in most conditions in which protein concentrations are abnormal ; a rise in relative concentration of the globulin components may merely reflect this reduction of albumin. The changes that occur in disease can be grouped under the following headings: Response to infection or injury ; effects of deficiency of protein ; changes due to excess of lipid in the serum ; changes associated with disease of the liver; changes in the serum of patients with myelomatosis. Examples of electrophoretic patterns in disease are given in Fig. 4 (pp. 188-191).

Response to Injury and Infection.-The changes in the concentrations of albumin and globulin in serum provoked by bacterial toxins are illustrated

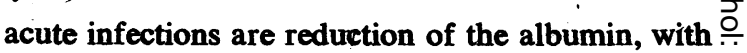
a rise in the $\alpha$-globulin during the acute stage and $\vec{\Rightarrow}$ a rise in the $\gamma$-globulin continued during the later $\stackrel{5}{?}$ stages and convalescence.

The most thorough studies of the electrophoretic $\frac{\overline{\bar{N}}}{\bar{N}}$ changes in acute infections are those of Dole and $\frac{\hat{\sigma}}{\bar{\phi}}$ his colleagues, in which they made repeated exami- $\varrho$ tions of the serum. They used barbiturate buffer is at $p \mathrm{H} 8.6$ and therefore separated $\alpha_{1}$-globulin from $\vec{\circ}$ albumin. Unfortunately in two of their reports they gave relative concentrations only, displayed $\vec{\omega}$ on charts. It is however possible to deduce the changes of absolute concentration when the? changes of relative concentration are more $i_{\omega}^{N}$ extreme. In three cases of scarlet fever (Dole, $\overrightarrow{-}$ Watson and Rothbard, 1945) in which arthritis 9 did not occur, the ratio of albumin to total protein fell and remained low for six or more weeks after the temperature had fallen to normal. The $D$ relative and absolute concentrations of $\alpha_{1}$-globulince were raised : in two of the cases the concentrations $\stackrel{\oplus}{\rho}$ remained high for seven weeks after the onset. $\vec{c}$ There was an absolute increase of the $\alpha_{2}$-globulin $\frac{f}{6}$ in two cases, highest in the first two weeks, and a moderate relative increase in a third. In twoo cases the relative concentration of $\gamma$-globulin was moderately raised. In the third a purulent infec-O

TABLE IX

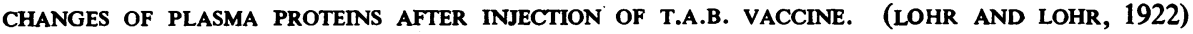

\begin{tabular}{|c|c|c|c|c|c|}
\hline \multirow{2}{*}{ Before Injection } & \multirow{2}{*}{ Temperature } & \multicolumn{4}{|c|}{ Proteins (g./100 ml.) } \\
\hline & & Total & Albumin & Globulin & Fibrinogen \\
\hline $\begin{array}{c}\text { After first injection } \\
\begin{array}{c}3 \frac{1}{2} \text { hours } \\
2 \text { days }\end{array}\end{array}$ & $100^{\circ}$ & $\begin{array}{l}7.34 \\
7.48\end{array}$ & $\begin{array}{r}4.94 \\
4.53\end{array}$ & $\begin{array}{l}1.99 \\
2.48\end{array}$ & $\begin{array}{l}0.41 \\
0.47\end{array}$ \\
\hline $\begin{array}{l}\text { After second injection } \\
2 \text { days }\end{array}$ & $102^{\circ}$ & $\begin{array}{l}7.04 \\
8.59\end{array}$ & $\begin{array}{l}4.35 \\
4.18\end{array}$ & $\begin{array}{l}2.10 \\
3.68\end{array}$ & $\begin{array}{l}0.69 \\
0.73\end{array}$ \\
\hline $\begin{array}{l}\text { Before third injection } \\
\text { After ," } \\
\\
\begin{array}{r}3 \text { 2 hours } \\
2 \text { days }\end{array}\end{array}$ & $102^{\circ}$ & $\begin{array}{l}8.57 \\
" ״ \\
8.56\end{array}$ & $\begin{array}{l}3.58 \\
3.75\end{array}$ & $\begin{array}{l}3.96 \\
" \Rightarrow \\
4.08\end{array}$ & $\begin{array}{c}0.73 \\
0.73\end{array}$ \\
\hline
\end{tabular}

by Löhr's (1921) study of the effects of injection of T.A.B. vaccine (Table IX). The concentration of albumin fell and that of globulin rose. The changes did not reach their height during the first reaction and progressed as the injections were continued. Similar changes that have been found in various infections will be mentioned later.

Electrophoretic Patterns in Acute Infections.As far as any generalization is possible from the limited number of cases reported, it may be said that the changes in the electrophoretic patterns in tion of the right maxillary antrum and ethmoid sinuses was found at the end of the second week.O At this time the temperature rose, and the relative concentration of $\gamma$-globulin rose to about three times the normal level and the antistreptolysin? O-titre to about 1,000. The infection of the sinuses cleared up under treatment in two days. Theo $\gamma$-globulin and titre then sank but were still high

The concentrations after $3 \frac{1}{2}$ hours are the same as before injection. about five weeks later. 
In three cases (J.K., G.S., and F.H.) in which rheumatic fever followed scarlet fever the relative concentrations of $\alpha_{1}$-globulin were raised in the early stages. In one case the absolute concentration was raised. Both relative and absolute concentrations of $\alpha_{2}$-globulin and $\gamma$-globulin were raised and in otwo cases the relative concentration remained high throughout the 160 days during which the sera were studied. In two of the cases (J.K. and G.S.) a detectable increase of the relative concentration of $\alpha_{2}$-globulin followed the cessation of sulphadiazine therapy and preceded a rise of temperature and the onset of pains in the joints in the fourth and fifth weeks. In the serum of G.S. the relative $\alpha_{1}$-globulin also rose. In the serum of J.K., who had a purulent nasal discharge from the seventh to the eighteenth day, the relative $\gamma$-globulin rose to about three times the normal and at the same time the antistreptolysin O-titre rose to over 2,000 . The titre then fell, though less rapidly than the relative $\gamma$-globulin concentration. In the other two cases the titre was low. It is an interesting point that patient J.K. had a large boil on the leg in the eleventh week. The white blood count then rose and the temperature and erythrocyte sedimentation rate rose slightly, but no change of the serum proteins was detected except a doubtful increase of the relative concentration of $\alpha_{1}$-globulin. In these cases the relative concentration of $\beta$-globulin was low or little changed.

In a case of typhus fever (Dole et al., 1947) the first sample of blood was taken on the fifth day of illness before the rash appeared and before the Weil-Felix reaction was positive. The main changes were those of the albumin and $\gamma$-globulin. The total protein was low in this sample, remained low for about three weeks and then rose above normal to about $8.5 \mathrm{~g} . / 100 \mathrm{ml}$. The absolute concentration of albumin was low throughout the seven weeks during which the serum was examined. The $\alpha_{1}$-globulin rose slightly at the end of the second week. The $\alpha_{2}$ - was high from the start and stayed high throughout. The relative $\gamma$-globulin was over twice the normal average in the first sample of serum, rose to well over-three times the normal and was still three times the normal at the end of seven weeks. Since the total protein rose the absolute concentration must have risen to about four times the normal average. In the cases of scarlet fever and rheumatic fever there was some evidence of a relation between the presence of specific antibodies and the rise of $\gamma$-globulin: In this case the $\gamma$-globulin was over double the normal average before specific antibodies were detected.

In most other studies by electrophoresis the $p H$ has been under 8.0. The $\alpha_{1}$-globulin has, therefore, not been separated from the albumin. In their early studies Longsworth et al. (1939) called attention to the increase in $\alpha$-globulin in the early stages of disease. Blix (1939) found that the absolute concentration of $\alpha$-globulin was raised in six out of seven cases of pneumonia and remained high after lysis. The highest figures were about three times the normal level given by Blix. The $\gamma$-globulin was not appreciably raised except in one case, and this patient died. Luetscher (1941) also found the $\alpha$-globulin raised to about twice the normal in one of two cases of pneumonia.

Rutstein and others (1945) found that the absolute and relative concentrations of $\gamma$-globulin were increased in cases of rheumatic fever both during attacks and during quiescent periods. The $\alpha$ globulin was increased less constantly. In two cases, examined during an acute attack, both $\alpha$ and $\gamma$-globulin were about double the normal. In 12 cases of rheumatic fever Malmros and Blix (1946) found that the $\alpha$-globulin was over $0.8 \mathrm{~g}$./ $100 \mathrm{ml}$. in all cases at the first time of examination. The $\beta$-globulin was normal. The $\gamma$-globulin was increased in all, the maximum being $3.4 \mathrm{~g} . / 100 \mathrm{ml}$. The same authors found that the $\alpha$-globulin was raised up to 0.7 to $1.0 \mathrm{~g} . / 100 \mathrm{ml}$. in cases of tonsillitis, and the increase persisted after the attack subsided. The absolute concentration of $\gamma$-globulin was appreciably raised in one of four cases during the attack and in all but one case after the attack.

In malaria transmitted by mosquitoes the liver is invaded by the malarial parasites at the beginning of the infection (Shortt et al., 1948), and there is considerable evidence of livendamage in glandular fever. The changes found in the acute stages of these diseases may be, in part, due to impairment of the functions of the liver. During the febrile stage of malaria artificially induced in three cases, the albumin fell in all three to $3.3 \mathrm{~g} . /$ $100 \mathrm{ml}$. or less. The $\alpha_{2}$-globulin also fell to about three-quarters of its previous level and the $\gamma$ globulin rose (Guttman et al., 1945). The reduction of the $\alpha_{2}$-globulin may have been due to the reduction of cholesterol thatoccurred in these sera during the attacks. Dole and Emerson (1945) studied the proteins in the serum of eight patients suffering from relapsing malaria in which $P$. vivax was found in the blood. The relation of the time of taking the blood to the attacks is not reported. The concentration of albumin was somewhat low, 
and the $\alpha_{1}$ - and $\gamma$-globulin moderately raised in three out of six cases. In a patient who had suffered from severe malaria due to $P$. falciparum for three weeks the concentrations of total protein and albumin were very low (3.64 and $1.5 \mathrm{~g} . / 100 \mathrm{ml}$.), the $\alpha_{1}$-globulin was normal and $\alpha_{2}-, \beta$-, and $\gamma$-globulin reduced.

In glandular fever Cohn and Lidman (1946) found that the albumin was not changed. The $\alpha_{2}$-globulin was moderately raised in four out of seven cases, and the $\gamma$-globulin was raised in all and over double the normal in one case. As bilirubin was detected in the urine of all these patients and the amount of bromsulphthalein retained in the blood after 30 minutes was abnormally high,
In the sera of three cases of advanced leprosy examined by Seibert and Nelson (1943) the $\alpha$ globulin was moderately raised and the $\gamma$-globulin raised to $2.0,2.8$, and $3.45 \mathrm{~g} . / 100 \mathrm{ml}$ :

Benditt and Walker (1948) examined the sera of syphilitic patients. Out of 15 cases, at all stages, the concentration of albumin was at the lower limit of normal or below normal in all but two. Of the globulin fractions, $\alpha_{1}$-globulin was little changed except in one case, $\alpha_{2}$-globulin was slightly raised, $\beta$-globulin was normal, and $\gamma$-globulin was above the normal means given by these authors in all cases. However, none of the globulin fractions were above the normal range given by Seibert et al., except that the $\gamma$-globulin was $2.09 \mathrm{~g} . / 100 \mathrm{ml}$.

TABLE $X$

MEAN CONCENTRATIONS OF PROTEINS (g./100 ml.) IN SERA OF PATIENTS WITH TUBERCULOSIS AND OTHER DISEASES (SEIBERT ET. AL., 1947)

\begin{tabular}{|c|c|c|c|c|c|c|c|c|}
\hline \multirow{4}{*}{$\begin{array}{l}\text { Normal } \\
\text { Tuberculosis }(a) \\
\text { Tuberculosis }(b) \\
\text { Tuberculosis }(c) \\
\text { Tuberculosis }(d) \\
\text { Tuberculosis }(e) \\
\begin{array}{l}\text { Sarcoidosis } \\
\text { Carcinoma }\end{array} \\
\begin{array}{l}\text { Diabetes } \\
\text { Diabetes with } \\
\text { tuberculosis }\end{array}\end{array}$} & \multirow{2}{*}{ Number } & \multirow{2}{*}{$\begin{array}{l}\text { Polysaccharide } \\
(\mathrm{mg} . / 100 \mathrm{ml} \text { ) }\end{array}$} & \multirow{2}{*}{$\begin{array}{l}\text { Total } \\
\text { Protein }\end{array}$} & \multirow{2}{*}{ Albumin } & \multicolumn{3}{|c|}{ Globulin } & \multirow[b]{2}{*}{$\gamma$} \\
\hline & & & & & $\alpha_{1}$ & $\alpha_{2}$ & $\beta$ & \\
\hline & $\begin{array}{r}43 \\
20 \\
22 \\
26 \\
21 \\
13 \\
11 \\
23 \\
6\end{array}$ & $\begin{array}{r}103 \\
109 \\
136 \\
159 \\
109 \\
112 \\
128 \\
145 \\
115\end{array}$ & $\begin{array}{l}7.29 \\
7.27 \\
7.67 \\
7.63 \\
7.17 \\
7.20 \\
7.88 \\
6.66 \\
7.16\end{array}$ & $\begin{array}{l}3.88 \\
3.62 \\
3.32 \\
2.69 \\
3.71 \\
3.54 \\
3.10 \\
2.80 \\
3.65\end{array}$ & $\begin{array}{l}0.58 \\
0.56 \\
0.64 \\
0.78 \\
0.59 \\
0.62 \\
0.61 \\
0.66 \\
0.50\end{array}$ & $\begin{array}{l}0.76 \\
0.78 \\
0.92 \\
1.21 \\
0.81 \\
0.84 \\
0.85 \\
1.09 \\
0.81\end{array}$ & $\begin{array}{l}1.01 \\
1.00 \\
1.15 \\
1.19 \\
1.00 \\
1.11 \\
1.26 \\
1.09 \\
1.23\end{array}$ & $\begin{array}{l}1.05 \\
1.30 \\
1.65 \\
1.76 \\
1.06 \\
1.08 \\
2.06 \\
1.03 \\
0.98\end{array}$ \\
\hline & 6 & 166 & 6.82 & 2.11 & 0.74 & 1.03 & 1.33 & 1.62 \\
\hline
\end{tabular}

(a) Active minimal pulmonary lesions. (b) Active, moderately advanced pulmonary tuberculosis. (c) Active, far advanced pulmonary tuberculosis. (d) Minimal pulmonary tuberculosis of questionable clinical significance. (e) Moderately advanced pulmonary tuberculosis of questionable clinical significance.

it may be inferred that the functions of their livers were impaired.

Electrophoretic Patterns in Chronic Infections. - Seibert et al. $(1942,1949)$ have made thorough studies of the relation of changes in serum proteins to the stage of tuberculosis (Table X). They found a wide spread in the values found both in normal subjects and in patients. The albumin might be as low as $3.4 \mathrm{~g} . / 100 \mathrm{ml}$. in normal subjects ; in the severest group, $c$ (Table $X$ ), it ranged from 1.6 to 3.4. The range of $\gamma$-globulin in normals was 0.59 to $1.46 \mathrm{~g} .100 \mathrm{ml}$.; in Group $c$ from 0.97 to 3.28. Seibert et al. (1947) discussed the significance of the deviations from the standard means. The variations from the normal of the mean concentrations of $\alpha_{1}$-globulin, $\gamma$-globulin, and of albumin and $\alpha_{2}$-globulin particularly in Group $c$ were highly significant. in one primary case and 1.47 and 1.80 in two secondary cases. Cooper, Craig, and Beard (1946) found rather larger changes in the $\gamma-$ and $\alpha_{1}$ globulins with no significant change in the $\alpha_{2}$ - and $\beta$-globulins. Cooper (1945) found the mean $\gamma$ globulin was doubled and the $\alpha$ - and $\beta$-globulins nearly doubled.

The great increase of total globulin in the serum of patients with lymphogranuloma venereum has been studied extensively by precipitation methods, but few electrophoretic studies have been made. Kabat, Moore, and Landow (1942) found that the $\gamma$-globulin made up 34 and $38 \%$ of the total serum protein in two cases. In one case mentioned by Gutman (1948) the concentration of albumin was 3.25 and that of $\gamma$-globulin, $5.1 \mathrm{~g} . / 100 \mathrm{ml}$.

$A$ number of investigators have found that the total protein and globulin are very high in the 
serum of kala azar patients and fall as the condition improves. Cooper, Rein, and Beard (1946) examined the sera of two patients. In the serum of one, who was clinically ill, the total protein was $12.1 \mathrm{~g} . / 100 \mathrm{ml}$., the $\gamma$-globulin 7.76 , and the albumin $2.62 \mathrm{~g} . / 100 \mathrm{ml}$. In the other case the total protein had been $8.9 \mathrm{~g} . / 100 \mathrm{ml}$. with $4.3 \mathrm{~g}$. $/$ $100 \mathrm{ml}$. of $\gamma$-globulin. After improvement the $\gamma$ globulin was still 2.46 , although the albumin had gone up to 4.35. In this disease, even more than in malaria and glandular fever, it is probable that the changes in the serum proteins are due both to infection and to lesions of the liver. In the first serum examined by Cooper et al. and in our case (Fig. 4.H) the mobility of the $\gamma$-globulin was slow. Cooper $e t$ al. consider that this $\gamma$-globulin may $\mathrm{d}$ :ffer from that found in excess in the serum in other infections and in diseases of the liver. Their serum did not give a positive formol-gel test, but the serum of our case (Fig. 4.H) gave the strongly positive reaction usual in kala azar sera.

Striking changes are found in some diseases of obscure origin which may be regarded as secondary responses to some chronic infection. In sarcoidosis, proved by biopsy, Fisher and Davis (1942) found that the albumin was low in active cases and the $\gamma$-globulin over 2.0 and might rise to $3.8 \mathrm{~g}$. $/ 100 \mathrm{ml}$. In the 11 cases studied by Seibert et al., included in Table X, the albumin was low. The $\alpha$-globulins were, at most, little raised in sarcoidosis whereas the average $\gamma$-globulin was higher than in active, far advanced pulmonary tuberculosis: The small and scattered sarcoid lesions found in the liver (Scadding and Sherlock, 1948) are not likely to affect the electrophoretic pattern. Seibert et al. (1947) suggest that the difference in electrophoretic pattern may be of value in diagnosis. But it is rather doubtful whether the pattern would be of much use owing to the wide spread of the values found in the two diseases.

In two sera from cases of lupus erythematosus, in which the total globulin was high, Coburn and Moore (1943) found that 22 and $46 \%$ of the protein was $\gamma$-globulin. The albumin was low and the $\alpha$ - and $\beta$-globulins normal. 'They found that the $\gamma$-globulin might still be high after clinical recovery. This may be due to damage to the liver as there may be some infiltration and increase of fibrous tissue in the liver.

Lovgren (1945) reported the distribution in the serum of patients with rheumatoid arthritis. In some of these the $\gamma$-globulin was over $33 \%$ of the total protein. In most of the cases the albumin was little reduced and the $\alpha$ - and $\beta$-globulins were normál. Malmros and Blix (1946) included seven cases diagnosed as rheumatoid arthritis. In three of these the $\gamma$-globulin was $3.0,3.1$, and $3.1 \mathrm{~g}$./ $100 \mathrm{ml}$. respectiveiy. One of these patient's had acute myocarditis and pleurisy, and a second an endocrine disorder. Dole and Rothbard (1947) followed up a case for eight months during which time the patient's condition improved considerably. The albumin was moderately reduced. Absolute concentrations of $\alpha_{1}^{-}, \alpha_{2}-$, and $\gamma$-globulins were raised compared with Dole's normals ( $\gamma$-globulin to about $1.5 \mathrm{~g} . / 100 \mathrm{ml}$.), but the albumin rose and the $\alpha_{2}$-globulin fell to normal at the end of eight months. The $\alpha_{1}$-globulin and $\gamma$-globulin remained high. In one serum, which we examined because it gave a strong thymol-turbidity reaction, the concentrations were albumin $3.2, \alpha$-globulin $1.0, \beta$-globulin 1.1 , and $\gamma$-globulin $3.9 \mathrm{~g} . / 100 \mathrm{ml}$.

Malmros and Blix (1946) examined the sera of nine cases of erythema nodosum. Two were classed as tuberculous and the remaining seven as rheumatic. The albumin was low in all. In four cases the $\gamma$-globulin was over 2 , and in seven the $\alpha$-globulin was over $0.7 \mathrm{~g}$. $/ 100 \mathrm{ml}$. ; maximum figures, $\gamma$-globulin 4.0 , and $\alpha$-globulin $1.3 \mathrm{~g} . / 100 \mathrm{ml}$.

The occurrence of an increase of $\alpha$-globulin in the early stages of acute infections and in the more active stages of chronic infections suggests that this increase is a response to the destruction of tissue. Cuthbertson and Tompsett (1935) found that the serum globulin rose to high levels after fractures of bones of the leg. The highest figures were found in the first week after the injury. At the same time the albumin fell. In one case manipulation under an anaesthetic was followed by an increase of the globulin to $9 \mathrm{~g} . / 100 \mathrm{ml}$. Shedlovsky and Scudder (1942) found no increase of globulin in the serum of one patient three days after his tibia and fibula were broken. In another case the total globulin was $3.0 \mathrm{~g} . / 100 \mathrm{ml}$. two days after fracture of a femur, and both $\alpha$ and $\beta$-globulin were moderately high. On the other hand Chambers and Gjessing (1946) found that the $\alpha_{1}$ - and $\alpha_{2}$-globulin in the serum of a dog were doubled in the first week after one tibia had been broken under an anaesthetic. Burns, subcutaneous injection of turpentine to produce a sterile abscess, and injection of bis ( $\beta$-chloroethyl) sulphide (Gjessing and Chambers, 1946) were all followed by an increase of $\alpha_{1}$ - and $\alpha_{2}$-globulin. Perlmann, Glenn, and Kauffman (1943) did not find a significant change in the $\alpha$-globulin in the serum of calves that had been severely burned. We (May and Hoch, 1949) examined the serum of a patient before and after his spleen was irradiated. Although the size of the spleen was very much 
reduced in a few days, the serum proteins did not change except for a slight rise of the $\alpha$-globulin (Fig. 4). Peterman, Karnofsky, and Hogness (1949) found no significant change in the electrophoretic patterns of the serum of patients with Hodgkin's disease and leukaemia after treatment with nitrogen mustards, methyl-bis ( $\beta$-chloroethyl) amine hydrochloride and tris $(\beta$-chloroethyl) amine hydrochloride, although these reagents destroy lymphoid and haematopoietic tissue and, occasionally, tumour tissue. In view of the changes found in various other diseases not necessarily associated with destruction of tissue, it is doubtful whether an increase of $\alpha$-globulin can be regarded as evidence of any special process.

Protein Patterns by Precipitation Methods.The maximum amount by which concentrations of the $\alpha_{1}$ - and $\alpha_{2}$-globulins increase are of the order of 0.4 and $0.8 \mathrm{~g} . / 100 \mathrm{ml}$., and some of the $\alpha$-globulin is left in solution with albumin. Increase of the $\alpha$-globulins, alone, will not produce a great increase in the total globulin. Since the albumin concentration is almost always reduced, increase of the $\alpha$-globulin, alone, will not produce an increase of the total protein. An increase of globulin is mainly due to increase of $\dot{\gamma}$-globulin. A great increase of globulin and an increase of total proteins are evidence of an increase of $\gamma$ globulin, with or without increase of $\alpha$-globulin.

Although the albumin estimated by the usual precipitation methods, such as by half saturation with ammonium sulphate or by Howe's method, exceeds that estimated by electrophoresis, the two estimates usually vary in the same direction. Thus Dole (1944) found that the albumin/globulin ratio found by Howe's method was about 1.5 times that found by electrophoresis both in normal sera and in sera from ill persons, including that of the typhus fever patient he studied.

It is usually found that the total globulin, estimated by salting out methods, rises during acute infection. Malmros and Blix (1946) used both salting out and electrophoresis in 25 sera of patients with rheumatic fever and tonsillitis. In five cases the increase shown by electrophoresis was missed by the salting out method. Moen and Reimann (1933) found that the globulin (Howe's method) of the serum of pneumonia patients might be appreciably raised on the second day of fever ; but the highest figure found was on the tenth day of the disease. The albumin fell in'all cases, so that the total protein was low. On the thirtieth and forty-eighth days, during convalescence, the globulin might still be over $3 \mathrm{~g} . / 100 \mathrm{ml}$. and the albumin still low. Stacey (1947) also found this. persistence of an increase in the globulin after th $\overrightarrow{\mathrm{E}^{2}}$ acute stage. The globulin in the serum of a patienf who had had an appendix abscess was still higlf after the appendix had been drained for 20 days

As a patient's clinical condition improves, th $\mathbb{8}$ albumin rises and the globulin falls. Thus the albumin rose from 3.9 to 5.6 and the globulin fell from 7.2 to $2.6 \mathrm{~g} . / 100 \mathrm{ml}$. in the serum of tuberculous patient as the condition improved $\vec{\omega}$ although, in another case, the albumin fell froner 5.4 to 5.1 , with a coincident fall of globulin from 3.4 to 2.6 when the patient improved and gained $15.5 \mathrm{lb}$. in weight (Eichelberger and McCluskey 1927). In rheumatoid arthritis Davis (1935-69, found that the globulin (Howe's method) fell from 3.9 to 3.0 with improvement in a severe case and rose again to 4.0 as the patient relapsed, and in another less severe case fell from 3.1 to 2.0 whe the patient recovered. However, in another severE case the globulin, as well as the albumin, rose although the patient felt better and had gaine $\$$ $7 \mathrm{lb}$. in weight,

When patients with lymphogranuloma venereun were treated with sulphanilamide the albumin rose and the globulin fell; thus in one case the cons centrations of proteins before and on the sevent量 and 212th days after treatment began were $\&$ Albumin, 1.86, 3.37, 3.75, and globulin, 5.8 $\overrightarrow{6}$ $4.28,2.60$ g./ $100 \mathrm{ml}$. (Schamberg, 1941).

In those conditions in which the increase of $\gamma$-globulin is highest, namely, typhus fever (Tierney and Yeomans, 1946), lymphogranuloma venereun (Schamberg, 1941), leprosy (Frazier and Wu, 1925) sarcoidosis (Fisher and Davies, 1942), kala aza (Ling, 1930), and some cases of rheumatoig arthritis (Davis, 1935-6), the total globulin measured by salting out methods is very mucb increased. In typhus fever the globulin max be high on the fifth day after onset, before the rash appears and before the Weil-Felix reactio becomes positive (Tierney and Yeomans, 1946) it rises to high levels (over $4 \mathrm{~g}$. $/ 100 \mathrm{ml}$.) angd remains high for five weeks after the temperat ture has fallen. These changes are comparable to the changes of $\gamma$-globulin found by Dole Yeomans, and Tierney (1947).

The $\gamma$-globulin is mainly precipitated in Howe euglobulin and pseudo-globulin I; these two fract tions may be taken together. The $\alpha$-globulins are included in the Howe's pseudo-globulin II and albumin fractions. (The normal distribution foung by Howe's method is given in Table II.) Moen and Reimann (1933) found that the pseudos 
globulin II was raised in some cases of pneumonia in early stages, but the eu- + pseudo-globulin I was'also raised and this fraction alone was raised in the later stages. In the subacute and chronic infective diseases the increase is almost always confined to the eu- + pseudo-globulin I fraction. Gutman and colleagues (1941) present a table that includes cases of lymphogranuloma venereum, sarcoid, lupus erythematosus, leprosy, and tuberculous adenitis in which this fraction was increased. Other examples are kala azar (Ling, 1930), and lupus erythematosus (Coburn and Moore, 1943). In rheumatoid arthritis the main change is in this fraction although the pseudo-globulin II may also be increased to an average level of $0.68 \mathrm{~g} . / 100 \mathrm{ml}$. in severe cases (Davis, 1935-6).

Other Protein Changes.-A protein, the Creactive protein, has been detected in the serum of patients suffering from acute infectious diseases, and has the characteristic of forming a precipitate with the somatic C-polysaccharide of pneumococci. The reaction differs from an ordinary precipitin reaction in that no precipitate is formed unless calcium ions are present in the solution (Abernethy and Avery, 1941). The presence of this protein in the serum is not characteristic of any particular infection. Strong reactions with the polysaccharide have been found in the serum of patients suffering from lobar pneumonia, other infections of the respiratory tract, miscellaneous purulent infections, septicaemia, Still's disease, typhoid fever, coli pyelitis, rheumatic fever, and tuberculosis (Ash, 1933). This protein was found in the sera of patients with rheumatoid arthritis by Dole, and Rothbard (1947) and Wallis (1946) have reported finding it in other cases. The reactions that Wallis found were weak. We examined a number of sera and found only one that reacted strongly with the polysaccharide. The C-reactive protein is precipitated by ammonium sulphate between 50 and 75 saturation; it appears to be an $\alpha_{1}$-globulin (Perlmann et al., 1943). It has been crystallized (McCarty, 1947). As an antigen it is different from other serum proteins. The amount of precipitate formed on mixing sera of patients with antisera to the C-reactive protein, suggests that the amount in these sera may be of the order of $0.1 \mathrm{~g} . / 100 \mathrm{ml}$. It contributes towards the increase of $\alpha_{1}$-globulin found in acute infections, just as the true antibodies contribute to the increase of the $\gamma$-globulin.

Blix, Tiselius, and Svensson (1941) noted the large amount of polysaccharide in the protein fractions of the serum of a patient with pneumonia,
Table V. The largest amount was in the $\alpha$-globulin. Seibert et al. in their analysis on the sera of patients with tuberculosis and.carcinoma found that the polysaccharide content of the serum rose with the $\alpha_{2}$-globulin and was not correlated with $\gamma$-globulin and albumin.

Cartwright and Wintrobe (1949) have found that the iron-binding capacity of serum, which is a measure of the concentration of the metalbinding protein, may be low or very low in the serum of patients suffering from infections and rise rapidly on recovery. The iron-binding capacity of the serum falls on the day of injection of typhoid vaccine and rises again on the following day. This reduction of iron-binding capacity is not the cause of the low concentration of serum iron and the anaemia of infections, as the metalbinding protein was less saturated than it normally is.

Effects of Deficiency of Protein.-Ancel Keys et al. (1946) found that the average serum proteins of a group of young men who lived for months on a diet that supplied little protein and insufficient calories fell by only $0.73 \mathrm{~g} . / 100 \mathrm{ml}$. The electrophoretic patterns were practically unchanged. These subjects lost much of their body protein and became oedematous, with a great increase in the extracellular water. Their condition resembled that found in famine oedema. In a large number of cases of famine oedema the serum albumin is much reduced.* However, in recent investigations, for example, Sinclair (1948) it has been found that the serum albumin is about normal in a large proportion of cases of famine oedema. It seems that oedema may be due to some additional cause as well as to the reduction of the serum albumin, and that some other factor besides loss of body proteins is involved when the albumin in the serum is reduced. Rytand (1942) studied a patient who had had recurrent oedema with low serum proteins for some years. There were no albumin or casts in the urine. The serum protein varied between 3.0 and $4.7 \mathrm{~g} . / 100 \mathrm{ml}$. The electrophoretic pattern was: albumin 2.83, $\alpha$-globulin $0.27, \beta$-globulin 0.70 , and $\gamma$-globulin $0.69 \mathrm{~g} . / 100 \mathrm{ml}$. In this case the diet was adequate and the defects seems to have lain in the synthesis of serum protein. In another case of recurrent oedema (Schick and Greenbaum, 1945), when the serum albumin was 3.3 and the globulin $0.8 \mathrm{~g}$./ $100 \mathrm{ml}$., no peak corresponding to $\gamma$-globulin was

*A list of investigations is given in Recommendations with regard to Methods of Investigation of Nutrition, (1945), issued by the Nutrition Society. 
seen. In this case the Schick and Dick tests were negative, so that the serum contained some antibodies, but the association of antibodies with $\gamma$ globulin was shown, as no agglutinins to typhoid bacilli and whooping-cough antibodies were formed in response to injection of vaccines. In a third case, a girl whose diet had been poor, the albumin was 2.0 and the globulin $1.1 \mathrm{~g}$. $/ 100 \mathrm{ml}$. when the patient was first seen (Krebs, 1946). Later the electrophoretic pattern was: albumin $1.81, \alpha$ globulin $0.49, \beta$-globulin 0.46 , and $\gamma$-globulin 0.16 . After two injections of typhoid vaccine no agglutinins were detected. The patient was given a high protein diet, and the albumin and $\gamma$-globulin rose to 2.54 and $0.68 \mathrm{~g} . / 100 \mathrm{ml}$. Deficiency of protein may therefore in some cases lead to reduction of $\gamma$-globulin as well as to reduction of albumin. For other examples see cases $F$ and $G$ (Fig. 4).

The great reduction of protein in the serum of patients with kidney disease and gross oedema was noted by Bright. Since Epstein (1917) attributed the gross oedema of nephrosis to reduction of the osmotic pressure of the serum proteins a very large number of observations have been made. . These have confirmed the close association of gross oedema with reduction of the serum albumin, although other factors àre certainly involved in causing oedema. The electrophoretic patterns found will be discussed in the section dealing with lipaemia. It has been suggested that the serum proteins in this condition may be abnormal. These apparent abnormalities are due to the use of impure fractions for study. Alving and Mirsky (1936) found in the plasma of nephrotic patients that the albumin fraction, that is, the protein not precipitated by half saturation with ammonium sulphate, had an abnormally low content of cystine. However, Brand et al. (quoted by Edsall, 1947) have found that certain $\alpha$-globulins contain relatively little cystine. $\alpha$-globulin makes up a relatively large proportion of the so-called albumin fraction, when the albumin concentration is low, and this $\alpha$-globulin accounts for these low cystine contents. The results obtained by Goettsch and Reeves (1936) and Goettsch and Lyttle (1940) using immunological methods can be explained by a quantitative change in the serum protein fractions. The preparations, used by Bourdillon (1939) for estimating the osmotic pressure of the albumin in the serum of nephrotic patients, certainly contained globulin which accounts for the low osmotic pressures. Other investigations (Hewitt, 1927, 1929 ; Widdowson, 1933) have detected no difference between the albumin of serum and urine.
Deficiency of protein is probably one of the fac을 tors that cause reduction of the concentration of serum proteins and changes in the electrophoretic patterns in a number of diseases. Seibert et af (1947) found that the mean concentration of the serum albumin of 23 patients with carcinoma wa尺 $2.8 \mathrm{~g} . / 100 \mathrm{ml}$. The $\alpha_{2}$-globulin was moderatel raised; this might be in response to destruces tion of tissue. If cases which had metastases i $\vec{B}$ the liver with jaundice were excluded, the mean $\gamma$-globulin was low. In most cases the $\gamma$-globuligh peak was much flattened. Low serum albumip was found in two out of three cases of carcinom (without secondaries in the liver) by Luetsche (1941), and in one of these the $\gamma$-globulin was low.

The albumin is particularly low in the serum of patients with carcinoma of the stomach (Abels et al., 1942). Peterman and Hogness (1948) exam=ining the serum of 25 patients with carcinoma of the stomach found that the albumin was undef $3 \mathrm{~g}$. $/ 100 \mathrm{ml}$. in all of them. The $\alpha_{1}$-globulin was in the upper range or above the range of normaxb found by these authors, but little raised as come pared with the normals of Seibert et al. The $\alpha_{2}$-globulin was slightly raised, but the $\gamma$-globulio was not low either in cases without or in cases with metastases. In these cases the $\alpha_{1}$-globulin fell on treatment with protein hydrolysates, buô the albumin did nor rise although the nitrogen balance was positive. Even after the primars tumours had been removed and the patients, with no obvious metastases, had eaten a normal dief for two months, the serum albumin was still undex. 3.6 g. $/ 100 \mathrm{ml}$. Peterman and Hogness also foun that the serum albumin was low in six cases of gastric ulcer.

Lipaemia.-The proteins to which lipids are attached are in the $\alpha$ - and $\beta$-globulins. It is there? fore to be expected that when the amount of lipis in the serum is raised the $\alpha$ - and $\beta$-globulins wi be raised. Lewis, Schneider, and McCullag (1944) found the $\beta$-globulin high in untreated diabetes mellitus, a condition in which the lipid尺 of the plasma are high, but on treatment thE $\beta$-globulin fell to normal. Longsworth et $a b$ (1945) point out that the sum of $\alpha$ - and $\beta_{0}$ globulin is higher than normal in the plasma of women immediately after childbirth and that if the plasma of blood taken from the umbilical cord this sum is lower than normal ; the concentratio of total lipids of plasma at the end of pregnanc\$ is nearly $150 \%$ and in cord blood only about $30 \%$ of the concentration in the plasma of norma adults. In hypothyroidism the cholesterol in-the 
plasma is increased and the $\beta$-globulin is high (Lewis and McCullagh, 1944).

In their early studies Longsworth et al. (1939) found that not only was the concentration of albumin in serum in nephrosis even lower than had been found by salt fractionation, but also that the concentrations of $\alpha$ - and $\beta$-globulins were increased. These observations have been confirmed by Longsworth and McInnes (1940), Luetscher (1940), and Maimros and Blix (1946). Thorn et al. (1945) made their electrophoresis runs at $p \mathrm{H} 8.6$ and found that the $\alpha_{1}$-globulin and $\gamma$-globulin were low. The increase of absolute concentrations of $\alpha_{2}-$ and $\beta$-globulin are less striking than those of the relative concentrations. Thus in the serum of a patient with gross oedema may be little raised although the total protein is low and the concentration of cholesterol in the serum is moderately raised. These patients are continually losing protein in the urine in amounts up to $20 \mathrm{~g}$. and more daily. If they lose their oedema they are found to be much wasted. It is reasonable to suppose that the changes found in the serum are a combination of changes due to loss of protein and to lipaemia, and are not a change peculiar to nephrosis. Extreme changes may be found as soon as one month after the appearance of oedema, as in case W.H. of Table XI.

As abnormally large amounts of lipids are associated with protein in the complexes that give rise to the $\alpha$-and $\beta$-peaks, the globulin is overestimated

TABLE XI

RELATION BETWEEN OFDEMA, CHOLESTEROL, AND PROTEIN COMPJNENTS (g./100 ml.) IN NEPHROTIC PLASMA (THORN et al., 1945)

\begin{tabular}{|c|c|c|c|c|c|c|c|c|c|c|c|c|c|c|c|}
\hline \multirow{2}{*}{ Case } & \multirow{2}{*}{ Oedema } & \multirow{2}{*}{$\begin{array}{l}\text { Chol- } \\
\text { esterol } \\
\text { (g./100 } \\
\text { ml.) }\end{array}$} & \multirow{2}{*}{$\begin{array}{c}\text { Total } \\
\text { Protein } \\
\text { (g./100 } \\
\text { ml.) }\end{array}$} & \multicolumn{2}{|c|}{ Albumin } & \multicolumn{2}{|c|}{$\alpha_{1}$} & \multicolumn{2}{|c|}{$\alpha_{2}$} & \multicolumn{2}{|c|}{$\beta$} & \multicolumn{2}{|c|}{$\varphi$} & \multicolumn{2}{|c|}{$\gamma$} \\
\hline & & & & $\mathbf{R}^{*}$ & $\mathbf{A} \dagger$ & $\mathbf{R}$ & $\mathbf{A}$ & $\mathbf{R}$ & A & $\mathbf{R}$ & A & $\mathbf{R}$ & $\mathbf{A}$ & $\mathbf{R}$ & $\mathbf{A}$ \\
\hline $\begin{array}{l}\text { J.R. } \\
\text { L.I. } \\
\text { W.H. } \\
\text { P.S. } \\
\text { K.N. }\end{array}$ & $\begin{array}{c}++++ \\
+++ \\
+++ \\
+++ \\
+\end{array}$ & $\begin{array}{l}1.10 \\
1.17 \\
0.755 \\
1.00 \\
0.43\end{array}$ & $\begin{array}{l}2.8 \\
3.8 \\
4.1 \\
5.3 \\
5.6\end{array}$ & $\begin{array}{r}7 \\
17 \\
17 \\
26 \\
37\end{array}$ & $\begin{array}{l}0.19 \\
0.65 \\
0.70 \\
1.38 \\
2.06\end{array}$ & $\begin{array}{l}4 \\
5 \\
5 \\
8 \\
6\end{array}$ & $\begin{array}{l}0.11 \\
0.19 \\
0.205 \\
0.42 \\
0.33\end{array}$ & $\begin{array}{l}42 \\
36 \\
21 \\
22 \\
15\end{array}$ & $\begin{array}{l}1.18 \\
1.37 \\
0.86 \\
1.16 \\
0.84\end{array}$ & $\begin{array}{l}28 \\
22 \\
38 \\
30 \\
22\end{array}$ & $\begin{array}{l}0.78 \\
0.84 \\
1.56 \\
1.59 \\
1.23\end{array}$ & $\begin{array}{l}16 \\
16 \\
15 \\
9 \\
12\end{array}$ & $\begin{array}{l}0.45 \\
0.62 \\
0.62 \\
0.47 \\
0.67\end{array}$ & $\begin{array}{l}3 \\
4 \\
4 \\
5 \\
8\end{array}$ & $\begin{array}{l}0.08 \\
0.15 \\
0.16 \\
0.26 \\
0.45\end{array}$ \\
\hline $\begin{array}{l}\text { E.B. } \\
\text { R.S.Serum }\end{array}$ & $\begin{array}{l}+ \\
\pm\end{array}$ & $\begin{array}{l}0.88 \\
0.34\end{array}$ & $\begin{array}{l}4.1 \\
5.6\end{array}$ & $\begin{array}{l}46 \\
32\end{array}$ & $\begin{array}{l}1.88 \\
1.79\end{array}$ & $\begin{array}{l}4 \\
5\end{array}$ & $\begin{array}{l}0.16 \\
0.28\end{array}$ & 20 & $\begin{array}{r}\mathbf{R}_{34} \\
1.12\end{array}$ & $\begin{array}{c}\mathrm{A} \\
1.4 \\
23\end{array}$ & 1.28 & 13 & 0.53 & 20 & $\begin{array}{l}0.12 \\
1.12\end{array}$ \\
\hline
\end{tabular}

$R *$ Relative concentration as percentage of total protein. At Concentration in $\mathrm{g} . / 100 \mathrm{ml}$.

the $\alpha_{2}$-globulin made up $42 \%$ and the $\beta$-globulin $28 \%$ of the total protein, but the absolute concentration of $\alpha$-globulin was only twice the normal and that of $\beta$-globulin was under the average normal.

The concentrations of cholesterol, phosphatides, and neutral fat in the serum are much increased in nephrosis (see case illustrated in Fig. 4J.), but the concentration of any lipids in sera which have been examined by electrophoresis have rarely - been reported. The relation to concentration of cholesterol is well illustrated by the data given in Table XI. Longsworth and MacInnes (1940) and later Blix and Pedersen (1947) have shown that the $\alpha$-and $\beta$-globulins of nephrotic sera are much reduced by extraction of the lipids ; extraction of normal sera has little effect. Longsworth and McInnes found that the concentration of $\beta$-globulin in a nephrotic serum, after extraction with ether, was below the normal average. As the case illustrated in Fig. 4A shows, the $\alpha$-and $\beta$-globulin when concentrations are calculated from the electrophoretic pattern, and, in consequence, the albumin is underestimated. Also albumin makes up an abnormally low proportion of the protein left in solution after precipitation by half-saturation with ammonium sulphate or by Howe's method. The discrepancy between the amounts of albumin found by electrophoresis and by salt fractionation is much greater in nephrotic sera than in other sera. However, neither albumin is the true albumin, in the sense of being free from associated globulin or lipid.

In the urine the albumin, as it has the lowest molecular weight, makes up a very much larger proportion of the total protein than in the serum. However, Luetscher (1940) found a considerable amount of $\gamma$-globulin in the urine of a patient with amyloid disease. From the figures of Longsworth and MacInnes (1940) it appears that the concentration of albumin in the urine is higher than in the plasma ; this is probably due to underestima- 
tion of the concentration of albumin in the plasma.

In other types of nephritis, not characterized by gross oedema and lipaemia, the serum proteins differ little from normal, the only change being a reduction of albumin.

Liver Disease.-The change of serum proteins characteristic of disease of the liver parenchyma is an increase of the $\gamma$-globulin. The albumin is reduced, sometimes to very low levels, and the other fractions are usually little changed. These changes, first detected by Luetscher (1940) have been reported by numerous observers (for example, Gray and Barron, 1943 ; Thorn, Armstrong, and Davenport, 1946) since. The relative concentration of $\gamma$-globulin is always raised; the absolute concentration is usually near $2 \mathrm{~g}$. $/ 100 \mathrm{ml}$., and may rise to 4 g. $/ 100 \mathrm{ml}$., but is sometimes little above normal (Thorn, Armstrong, and Davenport, 1946). Sherlock (1946) examined cirrhotic livers by biopsy ; she classed as "latent" those in which cell damage was minimal and bands of mature fibrous tissue disrupted the normal architecture and as "active" those with retrogressive parenchymatous changes and regeneration of surviving cells. The average concentrations of serum albumin and globulin in the active cases were 2.8 and $4.0 \mathrm{~g} . / 100 \mathrm{ml}$., and in the latent cases 4.2 and $2.5 \mathrm{~g} . / 100 \mathrm{ml}$. Cases in which the $\gamma$-globulin is little raised are probably latent.

With local lesions of the liver, such as metastases of carcinoma, the $\gamma$-globulin may be normal or may be raised to $2.4 \mathrm{~g}$. $/ 100 \mathrm{ml}$. (Gray and Barron, 1943). Obstruction of the bile ducts, unless associated with metastases in the liver or a secondary hepatitis, causes no significant change of serum proteins, or a rise of $\beta$-globulin due to increase of cholesterol in the serum.

In infective hepatitis Martin (1946) found that the relative concentration of $\gamma$-globulin was increased. The relative and absolute concentrations of albumin were moderately reduced in the early stages. The increases of absolute concentrations of $\gamma$-globulin were slight in five of the six cases in which absolute concentrations could be calculated. In the sixth the concentration was $1.76 \mathrm{~g} . / 100 \mathrm{ml}$. on the twenty-third day from the onset of symptoms. In this case excess of bromsulphthalein was retained 57 days after the onset and the $\gamma$-globulin was then $1.94 \mathrm{~g} . / 100 \mathrm{ml}$. In six cases of acute hepatitis (one arsenical jaundice and five catarrhal jaundice) Gray and Barron (1943) found $\gamma$-globulin concentrations of 2.85 and 3.0 g./100 ml. in two cases; in three others also the $\gamma$-globulin was above the normal range. The $\beta$-globulin was over $2 \mathrm{~g} . / 100 \mathrm{ml}$. in two cases $\stackrel{\circ}{\circ}$ (including the arsenical jaundice) but was not raised in the other cases.

Thorn, Armstrong, and Davenport (1946), usinge Howe's method, did not find the usual discrepancye between the amount of albumin estimated by salt fractionation and by electrophoresis. However Moore et al. (1941) found as big a discrepancy ines the serum of a hepatitis patient as in normal serum $\vec{\circ}$ In the serum of subjects intentionally infected with hepatitis, albumin estimated by these methods fell to a minimum and globulin rose to a maximum in the second week after the onset of symp toms. The albumin returned to its original leveE at the end of a month, but the globulin was still raised at the end of 60 days (Havens and Williams, 1948). The increase in the globulin is mainly? accounted for by a rise in Milne's fraction whichcorresponds to $\gamma$-globulin. As the albumin returned to normal while the globulin remainece high the total serum proteins were increased at? five to six weeks after onset. Rennie (1945) found that the globulin might continue to rise for somet months after the onset of acute hepatitis. In chronic hepatitis and cirrhosis of the liver the ratiog of albumin to globulin is correlated with activitys of the Kupffer cells and damage to cells of the liver parenchyma (Franklin et al., 1948). Post anco Patek (1942) found that patients with liver disease were more likely to recover when their serumo albumin was above $3.5 \mathrm{~g} . / 100 \mathrm{ml}$. Higgins and his colleagues (1944) found that 20 out of 24 patients who had recovered from hepatitis had. serum albumin over 3 g. $/ 100 \mathrm{ml}$. Sherlock (1946) using biopsy studies considered that the serum: albumin fell and globulin rose as the severity of the liver lesions of patients with acute hepatitis increased. She also found that albumin fell with the duration of obstructive jaundice and was noto more than $3 \mathrm{~g} . / 100 \mathrm{ml}$., in $60 \%$ of cases, whereas the globulin changed but little.

Myelomatosis.-Bence-Jones protein, which is excreted in the urine by about half the patients? suffering from multiple myeloma, has a molecular 0 weight of 37,000 (Svedberg and Pedersen, 1940) this is just over half the molecular weight of serump albumin. Its mobility in phosphate buffer $(p \mathrm{Hb}$ 7.4, ionic strength 0.2 ) ranges from 1.4 to 3.1 ; these values lie between the mobilities of $\beta$ - and ${ }^{\infty}$ $\gamma$-globulin or are equal to that of $\beta$-globulin. 7 Gutman et al. (1941) found that in most cases pre-

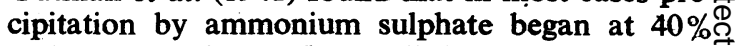
and was complete at 50 or a little over $50 \%$ satura- $-\frac{\mathbb{D}}{2}$ tion. Most of the Bence-Jones protein was noto usually precipitated from urine by $21.5 \%$ sodium 
sulphate unless the urine was made strongly acid. Antigenically, Bence-Jones proteins differ from normal serum proteins. Two types, differing antigenically, have been distinguished, but may occur together in the same urine (Hektoen and Welker, 1940).

On heating at neutral or slightly acid reaction Bence-Jones proteins coagulate at 45 to $58^{\circ} \mathrm{C}$. In many cases the coagulum redissolves on boiling. The resolution is promoted by the presence of salt, salts of divalent kations being more effective than those of univalent kations. The protein is reprecipitated on cooling. In other cases the coagulum does not redissolve on boiling but forms a dense curd which floats in the froth on the surface.

Gutman and his colleagues (Gutman et al., 1941 ; Moore et al., 1943 ; Gutman, 1948) have made a thorough study of the electrophoretic components of the serum of myelomatosis patients, and of the relation of these components to the BenceJones protein in the urine and the fractions found by Howe's method. They classed the sera in three groups: (1) Sera in which protein of the mobility of $\gamma$-globulin is increased and no Bence-Jones protein is detected by electrophoresis or ultracentrifugation (cf. Fig. 4D). (2) Sera in which various anomalous patterns are formed, usually with extra components of mobility equal to that of $\beta$-globulin or lying between those of $\beta$ - and $\gamma$-globulin ; in some cases the extra component is BenceJones protein. (3) Sera with apparently normal patterns. In groups (1) and (2) the concentration of albumin is low and often very low. Moore, Kabat, and Gutman (1943) found that the $\alpha$ globulin was increased in two cases. The sera studied by Longsworth, Shedlovsky, and McInnes (1939), Kekwick (1940), Blackman et al. (1944), Malmros and Blix (1946) and Martin (1947) fit into these groups. In one of the cases of Malmros and Blix the serum pattern was essentially normal at the first examination; a year later the albumin was low and both $\beta$ - and $\gamma$-globulin slightly increased. In one case studied by Moore, Kabat, and Gutman (1943) a very large $\beta$-component was found on one occasion, and on another a component of mobility between those of $\beta$ - and $\gamma$ globulin. Gutman et al. (1941) showed that the patterns found in Groups (1) and (2) could be reproduced by adding urinary Bence-Jones protein to normal serum. However, in most of the investigations made with the ultracentrifuge (McFarlane, 1935 ; Jersild and Pedersen, 1938 ; von Bonsdorff et al., 1938 ; Kekwick, 1943) no protein with the low sedimentation constant of Bence-Jones protein has been found in serum, but
Packalén (1939) found a protein of low molecular weight which crystallized. Moore, Kabat, and Gutman (1943) found components with low sedimentation constants in two sera; in one the mobility of the abnormal component was equal to that of $\beta$-globulin and in the other lay between those of $\beta$ - and $\gamma$-globulin. These components, therefore, had the physical properties of BenceJones proteins. However, in two other sera in which the abnormal component had a mobility between those of $\beta$ - and $\gamma$-globulin their sedimentation constants were equal to that of normal $\gamma$ globulin. In one of Kekwick's (1940) cases three abnormal components were found which had sedimentation constants above that of the bulk of the normal globulin. Abnormal components are therefore not usually identical with Bence-Jones protein. In a case of Moore et al., in which the abnormal component had a low sedimentation constant and mobility between those of $\beta$ - and $\gamma$-globulin, this component was antigenically identical with the Bence-Jones protein of the urine. In another serum which contained a large amount of. protein resembling normal $\gamma$-globulin in mobility and sedimentation constant, a small amount of Bence-Jones protein was detected immunologically.

Bence-Jones protein may be present in or absent from the urine in cases of all three groups. It was found in the urine in two of the three cases of Moore $e t$ al., in which its presence in the serum was established. Malmros and Blix (1946) found that on one occasion a patient's urine contained only traces of protein; a year later it contained $1.5 \%$ of Bence-Jones protein. On both occasions the serum contained a large amount of protein of mobility equal to that of $\beta$-globulin.

The same type of electrophoretic pattern may be found in the serum of patients with single tumours, multiple tumours, or generalized osteoporosis.

The total protein concentration in serum may be very high. In just over half of the 43 cases quoted by Gutman (1948) the concentration was over $8 \mathrm{~g} . / 100 \mathrm{ml}$. and in five it lay between 12 and $13.7 \mathrm{~g} . / 100 \mathrm{ml}$. In infective conditions, as already noted, any increase of the total globulin is usually accounted for by an increase of both Howe's euglobulin and pseudoglobulin I fractions. In myelomatosis the euglobulin fraction may remain low although the globulin is much increased; this may be found with sera of Groups (1) and (2). On the other hand the euglobulin fraction may be much increased in sera of both these groups. As Bence-Jones protein is but partially precipitated 
by $21.5 \%$ sodium sulphate, the concentration of albumin in sera that contain Bence-Jones protein, when estimated by Howes' method, may be much higher than that found by electrophoresis.

Part of the-calcium in serum is combined in an indiffusible form with pretein. This fraction varies with the concentration of albumin. As globulin binds relatively little calcium, the concentration of bound calcium in the serum of myeloma patients may be little increased (Gutman and Gutman, 1937) although the total protein is high. In some cases high concentrations of calcium are found in the serum. Laake (1949) ascribes these high concentrations to the mobilization of calcium from the bones.

Miscellaneous Diseases.-Various diseases that do not fall into the preceding groups have been studied. These include leukaemia and aplastic anaemia (Longsworth et al., 1939); leukaemia, lymphosarcoma and Hodgkin's disease. (Peterman, Karnosky, and Hogness (1948) ; hyper- and hypo-thyroidism (Lewis and McCullagh, 1944); Addison's disease (McCullagh and Lewis, 1945); Cushing's syndrome and acromegaly (Lewis and McCullagh, 1947). The albumin was usually low and the $\alpha$-globulin slightly raised, the degree of change varying with the severity of the disease ; with improvement of the condition the pattern reverted towards normal. In Addison's disease, the reduction of albumin was not in keeping with the severity of the disease. In one severe, untreated case the concentration was $4 \mathrm{~g} . / 100 \mathrm{ml}$., but in a moderate case it was 2.66 , and in a mild case $3.3 \mathrm{~g}$. $/ 100 \mathrm{ml}$. In eight cases of Cushing's syndrome the $\gamma$-globulin was low (Lewis and McCullagh, 1947). The increase of $\gamma$-globulin on treatment (for example, from 0.53 to $1.22 \mathrm{~g}$./ $100 \mathrm{ml}$.) was more striking than the increase of albumin.

Other Abnormal Proteins. - The abnormal component in the serum of one of the cases in the series of Moore, Kabat, and Gutman (1943) had a mobility between those of $\beta$ - and $\gamma$-globulin but was not Bence-Jones protein, and was studied further by Shapiro, Ross, and Moore (1943). It was. a viscous protein with a molecular weight of about 160,000 .

Lerner and Watson (1947) proposed that the - name " cryoglobulin" should be used for a group of proteins that have the property of precipitating or gelifying from cooled serum. They quote four examples described by other investigators. Shapiro and Wertheimer (1946) described another example in which a crystalline protein was separated from the serum of a patient with periarteritis nodosa옹 Four of the patients in the series quoted had: multiple myeloma.

Lerner, Barnum, and Watson (1947) examine $\Phi$ sera for the presence of cryoglobulin from patient with a number of diseases. They found thase small precipitates, of the order of $10-20 \mathrm{mg} . \vec{Q}$ $100 \mathrm{ml}$., formed on cooling the sera of patients with lymphatic leukaemia, congenital hypoprothrombinaemia, bronchopneumonia, bronchiecta sis, rheumatic heart disease, and subacute bacteria endocarditis. About $800 \mathrm{mg}$. of cryoglobuli precipitated from $100 \mathrm{ml}$. of the serum of a patieng with cardiovascular renal disease. This proteino (Lerner and Greenberg, 1946) was electrophoretici ally homogeneous at $p \mathrm{H} 4.7$; it was soluble $a \overrightarrow{\text { के }}$ $2^{\circ} \mathrm{C}$. in distilled water but almost completel $\overrightarrow{\mathrm{B}}$ insoluble in $0.5 \%$ solution of $\mathrm{NaCl}$; its molecular weight was 190,000 .

In McFarlane's (1935) studies of pathologica隹 sera there is no evidence of the presence of abnot mal proteins except in those derived from patients. with multiple myeloma. However, the components seemed to be less homogeneous than those o normal sera.

Peterman and Hogness (1948b) examined serê in acetate buffer at $p \mathrm{H}$ 4.0. Most of the serung protein is positively charged at this $p \mathrm{H}$, but the detected a protein which was negatively charge 9 and had therefore a low isolectric point. The sera from patients with carcinoma of the stomach? carcinoma of the lung, leukaemia, and Hodgkin's disease contained more of this protein than was found in the sera of normal persons or patients. with miscellaneous cancer.

In their second account of the copper-sulphat method of estimating the specific gravity Phillips. Van Slyke, et al. (1945) reported that the correop formula for calculating protein concentration ( $(P)$ from specific gravity $(G)$ should be

$$
P=377\left(G_{p}-1.0070\right)
$$

The values of $P$ calculated with this formula are. close to those calculated with the formula No

$$
P=364\left(G_{p}-1.0060\right)
$$

we recommended (Hoch and Marrack, 1945a) when the specific gravity is of the order of thate found with normal sera. Phillips et al. found that comparisons of specific gravities with proteio concentrations in sera from miscellaneous hospita星 patients measured by macro-Kjeldahl estimates give a mean value of 360 instead of 377 . for the cono stant. This would imply that the relation of the density of serum to the concentration of protein therein was abnormal, owiag either to the presence of abnormal proteins or to abnormal relative pro 
portions of the proteins. We found, however, that the values for the protein concentrations obtained by specific gravity methods, using our formula, agreed with those calculated from the Kjeldahl-N (x6.25) to within $4 \%$ with the sera of normal people, of those with malnutrition, and of women before and after childbirth (Hoch and Marrack, 1945a, b). The results of further experiments with nephritic sera and sera of patients with other diseases, including infective hepatitis, cirrhosis of the liver, coeliac disease, pernicious anaemia, and, albuminuria are shown in Fig. 5.

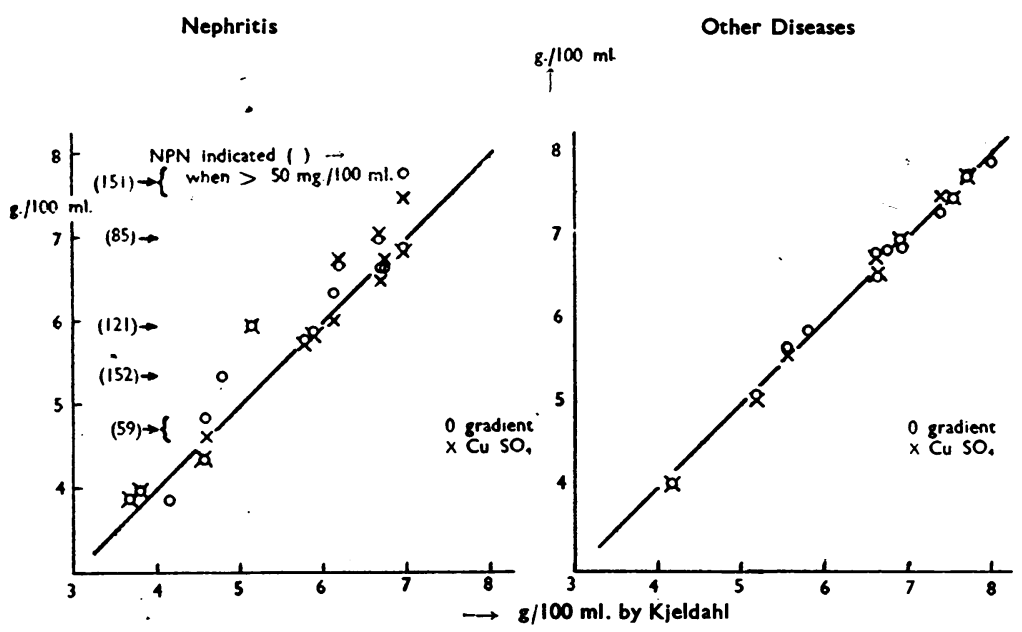

FIG. 5.-Relation of concentration of protein, calculated from the specific gravity, to the concentration calculated from the nitrogen content in pathological sera.

The errors ranged from +15.4 to $-7.0 \%$ in nephritis, but they were within $\pm 3 \%$ in all the other cases. There is therefore no evidence of an abnormal relation between specific gravity and protein concentration in these cases, and the same formula is applicable both to normal and to pathological sera.

\section{Flocculation Reactions}

In considering the relation of various aggregation and flocculation reactions to the fractions of serum proteins it should be remembered that these fractions, whether separated by precipitation with salts or by electrophoresis, are not homogeneous, nor is their composition constant. The $\alpha$-globulin of infectious conditions differs from that of nephrosis; and the $\gamma$-globulin of liver-disease from that of myelomatosis. It is probable, how: ever, that fibrinogen does not vary.

Most observers have found that electrophoretically isolated fractions produce effects similar to those in Table XII. There is some disagreement about the differences between the effects of fractions isolated from normal serum and from sera of patients with disease of the liver. Kabat et al. (1943) found that $\gamma$-globulin separated at $p H \mathbf{H} 7.4$ from normal and pathological sera (cirrhosis and hepatitis) did not differ in efficiency in flocculating either colloidal gold or cephalin-cholesterol. Moore $e t$ al. found both equally efficient in flocculating cephalin-cholesterol, and McLagan and Bunn found that in hepatitis $\gamma$-globulin was the more effective. On the other hand, Moore et al. (1945) found that hepatitis albumin separated at $p H \mathbf{H} 7.4$ was a less efficient inhibitor than normal albumin of the cephalin-cholesterol reaction. Kabat et al. found that albumin did not significantly inhibit this reaction. The differences between the effects of albumin may be due to differences in the amounts of some inhibiting constituent, other than albumin, in the preparations. Bernsohn and Borman (1947) found that a preparation of albumin which contains only $3 \%$ of $\alpha$-globulin made by the low - temperature - low salt - low-dielectric - constant method did not inhibit the colloidal gold reaction. It is remarkable that Guttman et al. (1945) found that the albumin isolated from the serum, taken during an attack of malaria, was more effective in inhibiting the cephalin-cholesterol reaction than was albumin isolated from serum taken before or after the attack. Bernsohn and Borman agreed with MacLagan and Bunn in finding that preparations containing $\beta$-globulin, without albumin, inhibited the colloidal gold. The effects of $\alpha$ - and $\beta$-fractions on the cephalin-cholesterol reaction may be due to their affinity for lipids.

The thymol-turbidity and thymol-flocculation reactions differ from the two other flocculation reactions in the importance of lipids. Phospholipids and cholesterol make up about one-third of the weight of the floccules formed with serum. The turbidity produced by isolated $\gamma$-globulin with the thymol reagent alone was very small. For this reason cephalin was added to the reagent used in the tests shown in Table XII. The main change produced in the electrophoretic patterns by floc- 
TABLE XI

EFFECT OF PROTEINS, SEPARATED BLECTROPHORETICALLY AT $p$ H 8.0, ON FLOCCULATION REACTIONS (MACLAGAN AND BUNN, 1947)

\begin{tabular}{|c|c|c|c|}
\hline Reaction & Flocculator & Inhibitor & $\begin{array}{l}\text { Difference between Proteins } \\
\text { of Normal (N) and } \\
\text { Hepatitis. (H) Sera }\end{array}$ \\
\hline $\begin{array}{l}\text { Thymol (cephalin) } \\
\text { turbidity }\end{array}$ & $\gamma$-globulin & Normal albumin & $\begin{array}{l}\text { H } \gamma \text {-globulin slightly more } \\
\text { effective than } \\
\mathrm{H} \text { albumin does not } \\
\text { inhibit }\end{array}$ \\
\hline $\begin{array}{l}\text { Thymol (cephalin) } \\
\text { flocculation }\end{array}$ & H $\gamma$-globulin & Not tested & $\mathrm{N}_{\text {flocculate }}^{\gamma \text { globulin does not } \frac{\sigma}{?}}$ \\
\hline $\begin{array}{l}\text { Colloidal gold, } p \mathrm{H} \\
7.8\end{array}$ & $\gamma$-globulin & Albumin, $\alpha$ - and $\beta$-globulin & $\begin{array}{l}\mathrm{H} \gamma \text {-globulin more effective } \\
\text { than } \mathrm{N} \text {. }\end{array}$ \\
\hline $\begin{array}{l}\text { Cephalin- } \\
\text { cholesterol }\end{array}$ & $\begin{array}{l}\gamma \text {-globulin } \\
\mathbf{H}(\alpha+\beta) \text {-glóbulin }\end{array}$ & Albumin & $\begin{array}{l}\text { H } \gamma \text { globulin much more } \\
\text { effective than } N \text {. } \\
N \alpha \text { - and } \beta \text { globulin do } \\
\text { not flocculate }\end{array}$ \\
\hline Takata-Ara & $\begin{array}{l}\text { H } \gamma \text {-globulin } \\
\mathbf{H}(\alpha+\beta) \text {-globulin* }\end{array}$ & H Albumin & \\
\hline
\end{tabular}

culation with the thymol reagent is a reduction of the relative area of the $\beta$-globulin peak (Cohen and Thompson, 1947). It is probable that this reduction is due to removal of lipid which contributes to the area of this peak. Kunkel and Hoagland (1947) suggest that some $\gamma$-globulin may form a light combination with lipid and that this fraction migrates with $\beta$-globulin. We have confirmed (Marrack, Johns, and Hoch, 1949) by immunological methods that the bulk of the protein in the floccules is $\gamma$-globulin. The intensity of the turbidity depends on the amount of lipid in the serum. Popper and colleagues (1949) demonstrated that absorption of a large meal of fat increased the intensity considerably. Kunkel and Hoagland found that in patients with acute hepatitis the intensity of the reaction ran parallel to the alterations of serum lipids in the earlier stages and of the $\gamma$-globulin during convalescence.

The positive flocculations tests found in diseases other than hepatitis and cirrhosis of the liver, for example, malaria, glandular fever, rheumatoid arthritis, and heart failure (Carter and MacLagan, 1946), are all probably due to an increase- of $\gamma$-globulin and a decrease of albumin, secondary in some cases to damage to the liver. The sera of multiple myeloma patients do not give positive thymol turbidity reactions (Kunkel and Hoagland, 1947). Other flocculation and precipitation reactions such as the cadmium-turbidity test (Wunderly and Wuhrman, 1947) and the zinc-sulphate reastion of Kunkel (1947) depend on an increase of $\gamma$-globulin in serum. In the series of sera examinged by Malmros and Blix (1946) the $\gamma$-globulin wæs over $2 \mathrm{~g} . / 100 \mathrm{ml}$. when the formol-gel reactiकु was positive.

Erythrocyte Sedimentation Rate-Gray and Mitchell (1942) studied the effects of electro. phoretically isolated fractions on the erythrocyte sedimentation rate. Fibrinogen increased the rate most, $\alpha$ - and $\beta$-globulin were less effective, and $\gamma$-globulin least. Albumin delayed sedimentation These four factors therefore affect the E.S.R., eve् if the efficiency of the globulin fractions does not change with disease. The rate is not necessarity correlated with the concentration of any one corte. ponent. Thus Shedlovsky and Scudder (1948) found that in infective conditions the E.S.R. was more closely correlated with the concentration $\alpha$-globulin than it was with the concentration of fibrinogen. In the series reported by Malmros and Blix (1946) the E.S.R. was high in some cases of multiple myeloma in which the only abnormalitiकs were reduction of the albumin and increase of $\gamma$-globulin. In these cases the $\gamma$-globulin was probably abnormal.

*According to the latest report (Surgenor, Strong, et at 1948) fibrinogen is the most effective protein, and the next most effective a carbohydrate-rich $a_{2}$-globulin, whicer also binds bilirubin. 


\section{Discussion}

The changes found in the electrophoretic patterns are not characteristic of any disease. The outstanding changes are reduction of albumin, an increase of $\gamma$-globulin or a moderate increase of $\alpha$-globulin. These are found in a variety of conditions. The increase in the relative areas of the $\alpha$ - and $\beta$-globulin peaks in the patterns in nephrosis appears to be secondary to an increase of the lipids of the serum, an increase that can be better detected by simpler means. The reduction of $\gamma$-globulin which may have a better claim to be regarded as specific of nephrosis is found in other conditions associated with deficiency of protein.

Owing to the wide spread of the concentrations of the components of normal serum, a component may change considerably without passing beyond the normal range. Such changes will not be detected unless the patient's serum is examined repeatedly. The average change found in one disease may be greater than the average found in another, but in individual cases the difference may be in the opposite direction; thus the highest concentration of $\gamma$-globulin found by Siebert $e t$ al. (1947) in tuberculosis was higher than any they found in sarcoidosis, in which high figures were more common.

The bulk fractions separated by electrophoresis or by any other method are complex mixtures of several small components. It cannot be expected that changes in these bulk fractions will measure or even detect changes in the various components. The maximum amount of an antibody found in human serum is about $1 \mathrm{mg} . / \mathrm{ml}$, and the standard deviation of $\gamma$-globulin, according to Siebert $e t$ al. (1947), is $2.2 \mathrm{mg} . / \mathrm{ml}$. It is only in sera of hyperimmunized animals that the amounts of antibody rise to several $\mathrm{mg}$. $/ \mathrm{ml}$., and are enough to show in the electrophoretic pattern, and when the antibody is precipitated by antigen, an appreciable reduction of a peak can be seen. Possibly the reduction of $\beta$-globulin which is often found in infections is due to reduction of the metal-combining protein which normally makes up about onequarter of this fraction.

The plasma of patients with haemophilia appears to lack the anti-haemophiliac globulin, but the electrophoretic pattern is normal in spite of its absence (Lewis et al., 1946). The amounts of other components are very small. The choline esterase (Surgenor, Strong, et al., 1949), makes up about $1 \%$ of the protein of fraction IV-6, which is a sub-fraction of fraction IV-4 (Table IV).

At present changes in the serum proteins characteristic of certain diseases are detected by the specific reactions of the antibody globulins that appear in these diseases. It is probable that other changes characteristic of certain types of disease will be detected by the reactions of other components, such as the reaction of the metal-binding protein with iron or the precipitation of the C-reactive protein with the C-polysaccharide. Such reactions may be less specific than those of antibodies but still be characteristic of a certain type of disease. The amounts of the fractions separated by electrophoresis or by other means will serve more as a measure of severity than as evidence of the nature of an illness. The empirical flocculation reactions, which appear to depend on quantitative as well as qualitative changes of the protein fractions, take an intermediate position, and should, in time, be replaced by less empirical tests.

The gross changes of the concentrations of albumin and $\gamma$-globulin can be detected by salting out methods. In liver disease the estimates of albumin usually agree with those found by electrophoresis. In nephrosis the concentration of albumin calculated from the electrophoretic pattern has little better claim to be called the true albumin than has the concentration obtained by salt fractionation. It remains to be seen how well the results obtained by methods proposed by Milne (1947) and Kibrick and Blonstein (1948) agree with those derived from electrophoretic patterns.

Like the E.S.R., abnormalities of the electrophoretic pattern are a measure of the clinical state of the patient rather than specific evidence of disease. The main interest of the study of abnormalities of the electrophoretic components of serum lies in the correlation of the degree of change to the clinical condition of the patient and in the investigation of the causes of these changes. 

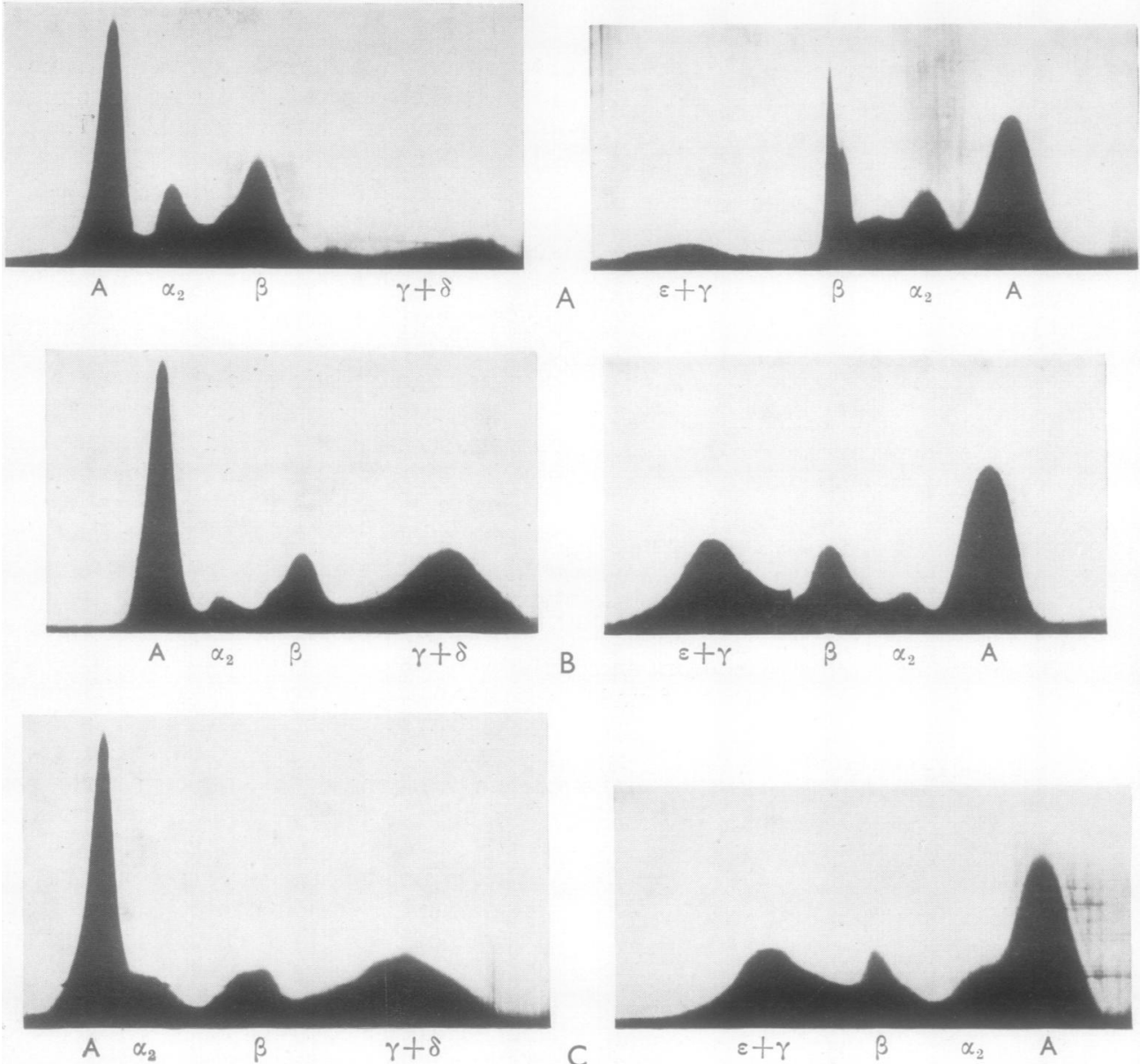

FIG. 4.-Electrophoretic patterns of (A) nephrosis, (B) cirrhosis of liver, (C) obstructive jaundice, (D1, D2) multiple myeloma, (E1, 2, 3) enlarged spleen (irradiated), (F) idiopathic hypoproteinaemia, (G) steatorrhea, (H) kala azar, and (J) nephrosis.

ELECTROPHORETIC ANALYSES OF SERA SHOWN IN FIG. 4

\begin{tabular}{|c|c|c|c|c|c|c|c|c|}
\hline \multirow[t]{2}{*}{$\therefore$} & \multirow{2}{*}{$p \mathrm{H}$} & \multirow{2}{*}{$\begin{array}{l}\text { Serum Diluted } \\
\text { to } \mathrm{g} . / 100 \mathrm{ml} \text {. }\end{array}$} & \multirow{2}{*}{$\begin{array}{l}\text { Total Protein } \\
\text { g. } / 100 \mathrm{ml} .\end{array}$} & \multirow{2}{*}{$\begin{array}{l}\text { Albumin } \\
\text { g. } / 100 \mathrm{ml} \text {. } \\
(\%)\end{array}$} & \multicolumn{4}{|c|}{ Globulin g./100 ml. $(\%)$} \\
\hline & & & & & $x_{1}$ & $x .2$ & $\beta$ & $\gamma$ \\
\hline $\begin{array}{l}\text { A } \\
\text { B } \\
\text { C } \\
\text { D1 } \\
\text { E1 } \\
2 \\
3 \\
F^{-} \\
\text {H } \\
\text { J }\end{array}$ & $\begin{array}{l}8.0 \\
8.0 \\
8.0 \\
8.6 \\
\\
8.6 \\
\\
8.6 \\
8.6 \\
8.0\end{array}$ & $\begin{array}{c}1.15 \\
1.25 \\
1.4 \\
1.4 \\
\\
1.4 \\
\\
1.4 \\
1.4 \\
0.8 \\
\text { aalysed }\end{array}$ & $\begin{array}{l}4.3 \\
7.3 \\
7.0 \\
7.6 \\
5.8 \\
6.1 \\
6.1 \\
4.4 \\
5.2 \\
8.7\end{array}$ & $\begin{array}{r}1.9 \\
2.9 \\
3.1 \\
3.3(43.0) \\
2.95(48.5) \\
2.75(47.5) \\
2.60(43.0) \\
2.1(47.5) \\
1.7(33.0) \\
2.4\end{array}$ & $\begin{array}{l}44.0) \\
40.0) \\
44.0) \\
0.3(4.0) \\
0.6(9.5) \\
0.5(9.0) \\
0.75(12.0) \\
0.4(9.0) \\
0.7(13.5) \\
27.5)\end{array}$ & $\begin{array}{l}0.7(16.5) \\
0.5(17.0) \\
0.7(10.0) \\
0.7(9.5) \\
0.90(15.0) \\
0.95(16.0) \\
1.20(19.0) \\
0.7(16.0) \\
1.1(21.0) \\
0.4(4.5)\end{array}$ & $\begin{array}{l}1.2(28.0) \\
1.4(19.0) \\
1.2(17.0) \\
0.8(11.0) \\
0.95(15.5) \\
1.00(17.0) \\
0.95(15.5) \\
0.9(20.5) \\
0.7(13.5) \\
0.8(9.0)\end{array}$ & $\begin{array}{l}0.5(11.5) \\
2.5(34.0) \\
2.0(29.0) \\
2.5(33.0) \\
0.70(11.5) \\
0.60(10.5) \\
0.60(10.5) \\
0.3(7.0) \\
1.1(21.0) \\
5.1(59.0)\end{array}$ \\
\hline
\end{tabular}

A.-Nephrosis. History of oedema for 10 months. Blood pressure, 130/85; renal efficiency tests normal ; plasma 8 cholesterol, $0.33 \mathrm{~g} . / 100 \mathrm{ml}$. $\quad \gamma$-globulin low in spite of respiratory infection one month before sample taken.

B. Cirrhosis OF Liver.-Jaundice; ascites; thymol turbidity 16 units.

C. OBSTRUCTIVE JAUNDice.-Carcinoma of pancreas; chronic hepatitis; thymol turbidity, 2.5 units; colloidalō. gold, 0 ; cephalin-cholesterol, 0 . 

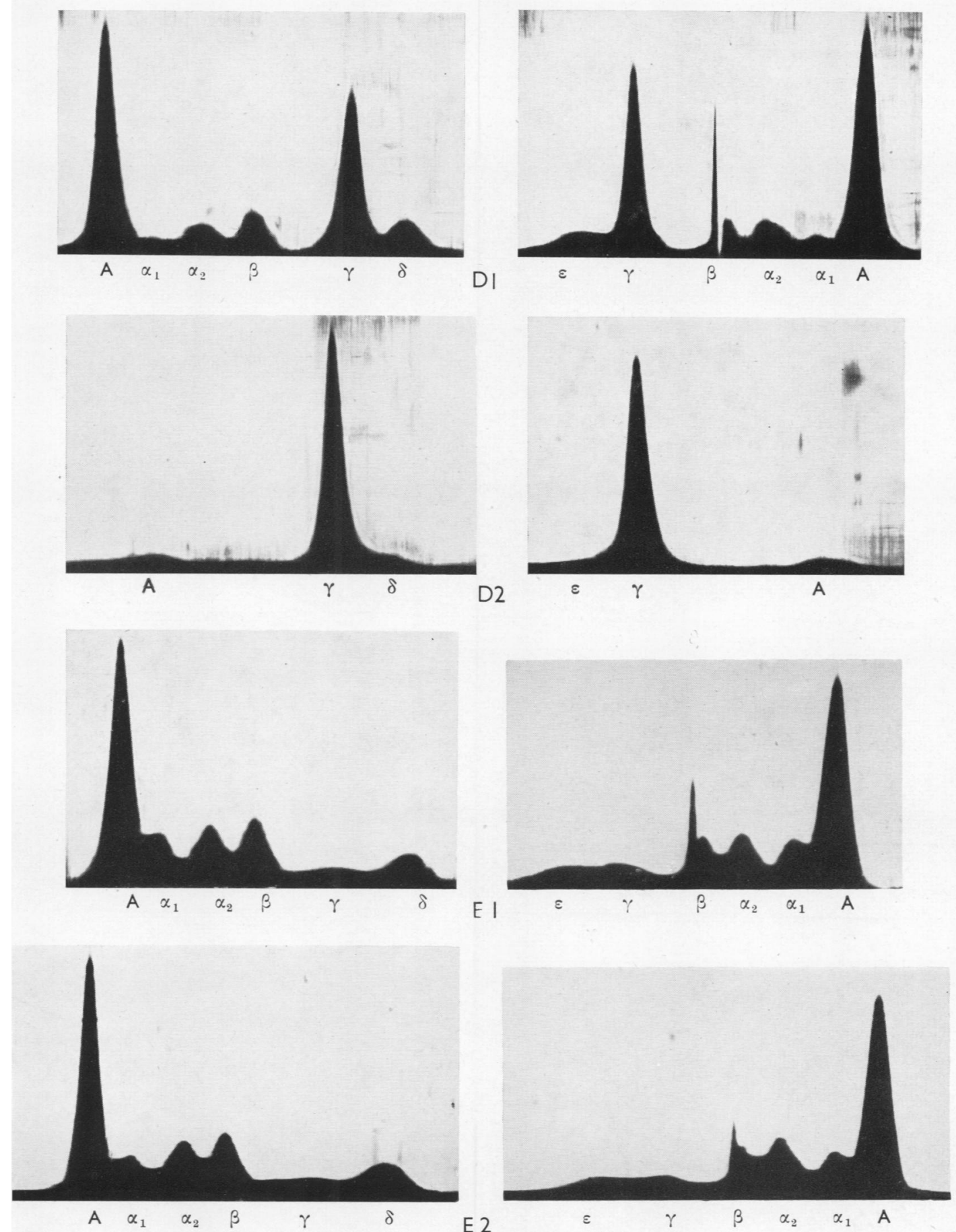

D. Multiple Myeloma (1) serum, (2) urine.-X-ray examination showed multiple punched-out areas in bones. Thymol turbidity, 3 units; E.S.R. (Wintrobe), $18 \mathrm{~mm}$./1 hour.' Urine contained a little albumin and much Bence-Jones protein which did not redissolve on boiling.

E. ENLARGED SPLEEN (irradiate 1).- - (1) Before irradiation; (2) one day after irradiation (see over). 
Ascending
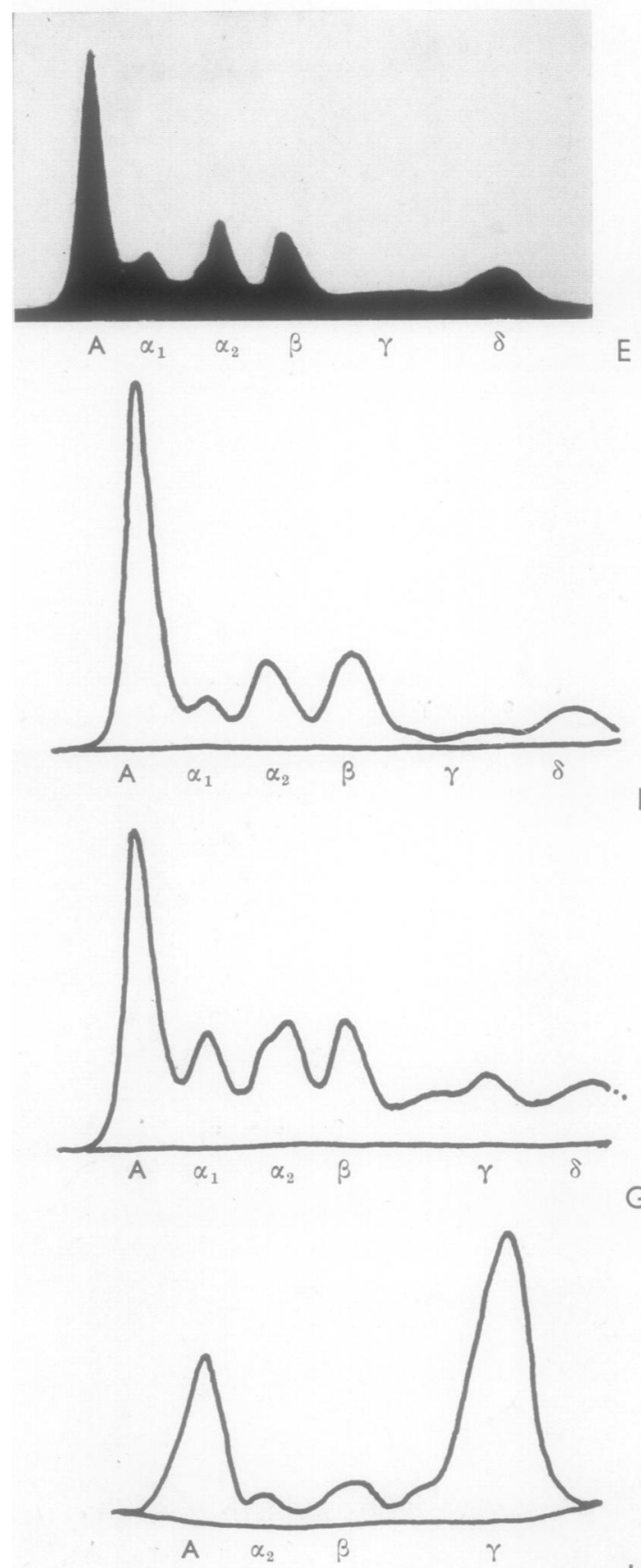

Descending

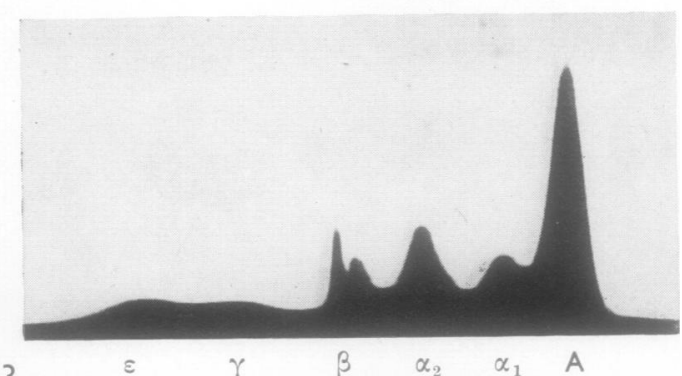

E 3
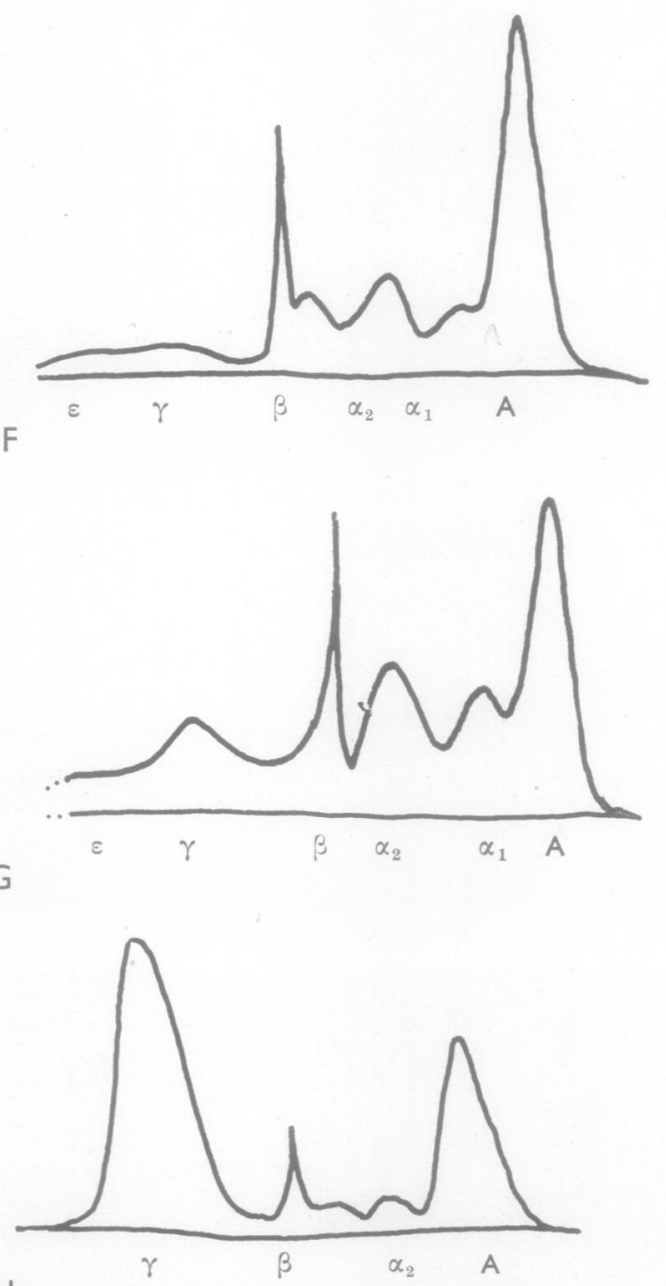

$\mathrm{H}$

E. ENLARGED SPLEEN (irradiated). - (1) and (2) see p. 188; (3) six days after irradiation.

F. IDEOPATHIC HYPOPROTEINAEMIA (? coeliac disease).

G. STEATORRHEA.-Subject very emaciated; voluminous fatty stools; serum calcium, $6.5 \mathrm{mg} . / 100 \mathrm{ml}$.

H. KALA AZAR.-Jaundice; thymol turbidity, 26 units. 

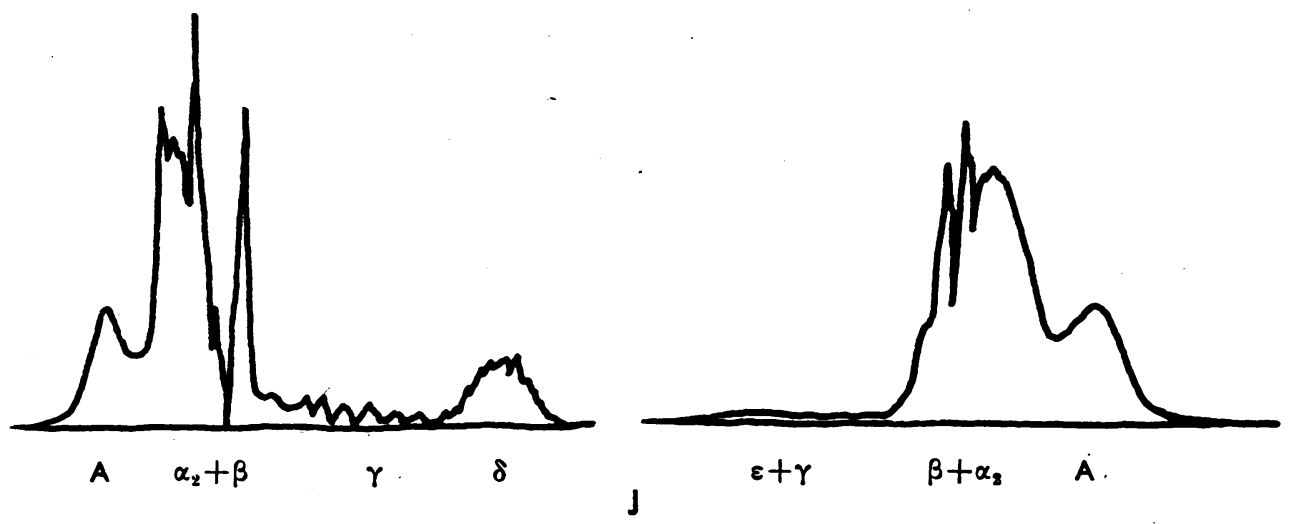

FiG. 4

J. NePHROSIs. - Subject had oedema since pregnancy 10 months previously. Gross oedema with effusions; blood pressure, 180/100; blood urea, $42 \mathrm{mg} . / 100 \mathrm{ml}$.; plasma cholesterol, $1.25 \mathrm{~g} . / 100 \mathrm{ml}$. Received two injections T.A.B. vaccine. Agglutinin titres, typhoid-H to 1/2560, typhoid $O$ to $1 / 04)$, although $\gamma$-globulin low.

\section{REFERENCES}

Abels, J. C., Rekers, P. E., Binkley, G. E., Pack, G. J., and Rhoads, C. P. (1942). Ann. intern. Med., 16. 221.

Abernethy, T. J., and Avery, O. T. (1941). J. exp. Med., 73, 173.

Alberty, R. A. (1948). J. Amer. chem. Soc., 70, 1675.

Alving, A. S., and Mirsky, A. E. (1936). J. clin. Invest., 15, 215.

Armstiong, S. H., Jr., Budka, M. J. E., and Morrison, K.C. (1947a). J. Amer. chem. Soc., 69, 416.

Armstrong, S. H. Jr., Budka, M. J. E., Morrison, K. C., and Hasson, M. (1947b). J. Amer. chem. Soc. 69, 1747.

Ash, R. (1933). J. infect. Dis., $53,89$.

Barr, M., and Glennie, A. T. (1931). Brit. J. exp. Path., $12,337$.

Benditt, E. P., and Walker, S-A. (1948). Amer. J. Med., 4, 663.

Bernsohn, J., and Borman, E. K. (1947). J. clin. Invest., 26, 1026.

Blackman, S. S. Jr., Barker, W. H., Buell, M. V., and Davis, B. D. (1944). J. clin. Invest., 23, 163.

Blix, G. (1939). Z. ges. exp. Med. 105, 595.

Blix, G., and Pedersen, K. O. (1947). Act. chem. scand., 1, 511. Blix, G., Tiselius, A., and Svensson, H. (1941). J. biol. Chem., 137,

Bonsdorff, B. von, Groth, H., and Packalen, T. (1938). Folia Haemat., 59,184

Bourdillon, J. (1939). J. exp. Med., 69, 819.

Boyd, W. C. and Bernard. H. (1937). J. Immunol., 33, 111

Brand, E. (1946). Ann. N.Y. Acad. Sci., 17, 187.

Brand, E., Kassell, B., and Saidel, L. J. (1944). J. clin. Invest., $23,437$.

Brand, E., Saidel, L. J., Goldwater, W. H., Kassely, B., and Ryan, F. J.'(1945). J. Amer. chem. Soc., 67, 1524.

Campbeli, W. R., and Hanna, M. I. (1937). J. biol. Chem., 119, 15.

Carter, A. B., and MacLagan, N. F. (1946). Brit. med. J., 2, 80.

Cartwright, G. E., and Wintrobe. M. M. (1949). J. clin. Invest., 28, 86.

Chanutin, A., and Gjessing, E. C. (1946). J. biol. Chem., 165, 421.

Chow, B. F. (1947). J. biol. Chem., 167, 757.

Coburn, A. F., and Moore, D. H. (1943). Bull. Johns Hopk. Hosp., $73,196$.

Cohen, P. P., and Thompson, F. L. (1947). J. Lab. clin. Med., 32, 475.

Cohn, E. J. (1948). Blood, 3, 471.

Cohn, C., and Lidman, B. I. (1946). J. clin. Invest., 25. 145.

Cohn, E.' J., McMeekin, T. L., Oncley, J. L., Newell, J. M., Hughes, W. L., Jn., (1940). J. Amer. chem. Soc., 62, 3381.

Cohn, E. J., Strong, L. E., Hughes, W. L., Jn., Mulford, D. J., Ashwoth, J., Melin, M., Taylor, H. L. (1946). J. Amer. chem. Soc., $68,459$.

Cooper, G. R., Rein, C. R., and Beard, J. W. (1946). Proc. Soc. exp. Biol. Med., 61, 179.

Cooper, G. R., Craig, H. W., and Beard, J. W. (1946). Am. J. Syph., $30,555$.

Cooper, J. A. (1945). J. Invest. Derm., 6, 109.

Cutherbertson, D. P., and Tompsett, S. L. (1935). Brit. J. exp. Path., $16,47$.

Darrow, D. C., and Cary, M. K. (1933). J. Pediat., 3, 573.

Davis, B. D., Moore, D. H., Kabat, E. A., and Harris, A. D. (1945). $J$ Immunol. 50 . 1.

Davis, J. S. (1935-36). J. Lab. clin. Med., 21, 478.

Deutsch, H. F., Alberty, R. A., and Gosting, L. J. (1946). J. biol. Chem., 168, 21.
Deutsch, H. F., Alberty, R. A., Gosting, L. J., and Williams, J. W. (1946). J.Immunol., 56, 183.

Dole, V. P. (1944). J. clin. Invest., 23, 708.

Dole, V. P. (1945). J. Amer. chem. Soc., 67, 1119

Dole, V. P., and Emerson K., Jr. (1945). J. clin. Invest. $24,644$.

Dole, V. P., and Rothbard S. (1947). J. clin. Invest. 2687.

Dole, V. P., Watson, R. F., and Rothbard, S. (1945). J. clin. Invest., $24,648$.

Dole, V. P., Yeomans, A., and Tierney, N. A. (1947). J. clin. Invest., $26,298$.

Ecker, E. E., Seifter, S., and Dozois, T. F. (1945). J. Lab. clin. Med., 30,39

Edsall, J. T. (1947). Adv . nces in Protein Chem., 3, 383.

Eichelberger, L., and McCluskey, K. L. (1927). Arch. intern. Med. 40,831 .

Epstein, A. A. (1917). Amer. J. med. Sci., 154, 638.

Erickson, J. O., Volkin, E., Craig, H. W., Cooper, G. R., Neurath, H. (1947). Amer. J. Syph., 31, 347

Fisher, A. M., and Davies, B. D. (1942). Bull. Johns Hopk. Hosp., 7i, 364.

Franklin, M., Popper, H., Steigmann, F., and Kozoll, D. D. (1948). J. Lab. clin. Med., 33, 435 .

Frazier, C. N., and Wu, H. (1925). Amer. J. trop. Med., 5, 297.

Gjessing, E. C., and Chanutin, A. (1946). J. biol. Chem., 165, 413.

Goettsch, E., and Lyttle, J. D. (1940). J. clin. Invest. 19, 9.

Goettsch, E., and Reeves, E. B. (1936). J. clin. Invest.. 15, 173.

Gray, S. J., and Barron, E. S. G. (1943). J. clin. Invest., $22,191$.

Gray, S. J., and Mitchell, E. B. (1942). Proc. Soc. exp. Biol. Med., $51,403$.

Gutman, A. B. (1948). Advances in Protein Chem., 4, 155.

Gutman, A. B., and Gutman, E. B. (1937). J. clin. Invest., 16, 903.

Gutman, A. B., Moore, D. H., Gutman, E. B., McClellan, V., and Kabat, E. A. (1941). J. clin. Invest., $20,765$.

Guttman, S. A., Potter, H. R., Hanger, F. M., Moore, D. B., Pierson P. S., and Moore, D. H. (1945). J. clin. Invest., $24,296$.

Havens, W. P., and Williams, T. L. (1948). J. clin. Invest., 27, 340.

Heidelberger, M. (1941). J. exp. Med., 73, 681.

Hektoen, L., and Welker, W. H. (1940). Biochem. J., 34, 487.

Hewitt, L. F. (1927). Biochem. J., 21, 1109.

Hewitt, L. F. (1929). Lancet, 1, 66.

Hewitt, L. F. (1937). Biochem. J.' 31, 360.

Hewitt, L. F. (1938). Biochem. J., 32, 1540

Hickmans, E. M., Finch, E., and Tonks, E. (1943). Arch. Dis. Childh. 18, 96.

Higgins, G., O'Brien, J. R. P., Stewart, A., and Witts, L. J. (1944) Brit. med. J., 1, 211.

Hoch, H. (1947). Unpublished.

Hoch, H., and Marrack, J. R. (1945a). Brit. med. J., 2, 151.

Hoch, H., and Marrack, J. R. (1945b). Brit. med. J., 2, 876.

Hoch, H., and Marrack, J. R. (1948). J. Obstet. Gynaec. Brit. Emp., 35, 1 .

Howe, P. E. (1921). J. biol. Chem., 49, 93, 109

Jager, B. V., and Nickerson, M. (1948). J. biol. Chem., 173, 683.

Jager, B. V., Smith, E. L., Nickerson, M., and Brown, D. M. (1948). J. biol. Chem., 176, 1177 .

Janeway, C. A. (1943). New Engl. J. Med., 229, 751, 779.

Jersild, M., and Pedersen, K. O. (1938). Acta path. microbiol. scand., 15, 426. 
Kabat, E. A. (1939). J. exp. Med., 69, 103.

Kabat, E. A. (1943). J. Immunol., 47, 513.

Kabat, E. A. (1946). Ann. Rev. Biochem., 15, 505.

Kabat, E. A., Hanger, F. M., Moore, D. H. and Landow, H. (1943).

Kabat, E. A., Moore D. H.. and Landow, H., (1942). J. clin. Invest., 21, 57!

Kekwick, R. A. (1940). Biochem. J., 34, 1248

Keys, A., Taylor, H. L., Mickelsen, O., and Henschel, A. (1946). Science, 103, 669

Kibrick, A. C., and Blonstein, M. (1948). J. Biol. chem., 176, 983.

Koechlin, B. A. (1949). Quoted by Surgenor et al. (1949).

Koenig, V. L., Perrings, J. D., and Hogness, K. R. (1946). Arch. Biochem., 11, 345 .

Krebs, E. G.'(1946). J. Lab. clin. Med., 31, 85

Kunkel, H. G. (1949). Proc. Soc. exp. Biol. Med., 66, 217.

Kunkel, H. G., and Hoagland, C. L. (1947). J. clin. Invest., 26, 1060.

Laake, H. (1949). Acta med. scand., 132, 440.

Lerner, A. B., Barnum, C. P., and W atson, C. J. (1947). Amer. J. med. Sci., 214, 416.

Lerner, A. B., and Greenberg, G. R. (1946). J. biol. Chem., 162, 429.

Lerner, A. B., and Watson, C. J. (1947). Amer. J. med. Sci., 214, 410.

Lewis, J. H., Davidson, C. S., Minot, G. R., Soulier, J. P., Tagnon, H. P., and Taylor, F. H. L. (1945). J. clin. Invest., 25, 870 . Lewis, L. A., and McCullagh, E. P. (1944). Amer. J. med. Sci.,
208, 727.

Lewis, L. A., and McCullagh, E. P. (1947). J. clin. Endocrinol., T, 559.

Lewis, L. A., Schneider, R. W., and McCullagh, E. P. (1944). J. clin. Endocrinol. 4, 535.

Ling, S. M. (1930). Proc. Soc. exp. Biol. Med., 27, 247.

Löhr, W., and Löhr, H. (1922). Z. ges. exp. Med., 29, 139.

Longsworth, L. G. (1942). Chem. Rev., 30, 323. Longsworth, L. G., and MacInnes, D. A. (1940). J. exp. Med.,

Longsworth, L. G., Curtis, R. M., and Pembroke, R. H., Jr. (1945). J. clin. Invest., 24, 46

Longsworth, L. G., Shedlovsky, T., and MacInnes, D. A. (1939). J. exp. Med., 70, 399.

Lövgren, O. (1945). Acta med. scand., Suppl., 163, 61.

Luetscher, J. A., Jr. (1940). J. clin. Invest., 19, 313,

Luetscher, J. A., Jr. (1941). J. clin. Invest., $20,99$.

Luetscher, J. A., Jr. (1947). Physiol. R ev., 27, 621.

Malmros, H., and Blix, G. (1946). Acta med. scand., Suppl., 170, 280.

Marrack, J. R. (1938). Chemistry of Antigens and Antibodies. Med. Res. Council Spec. Rept., No. 230. London, H. M. Stationery Office, p. 165 .

Marrack, J. R., and Duff, D. A. (1938). Brit. J. exp. Path., 19, 171.

Marrack, J. R., Johns, R. G. S., and Hoch, H. (1949). In press.

Martin, N. H. (1946). Brit. J. exp. Path., 27, 363.

Martin, N. H. (1947). J. clin. Invest., 26, 1189

Martin, N. H. (1949). J. Amer. chem. Soc., 71, 1230

Martin, N. H., and Morris. R. (1949). J. clin. Path., 2, 64

May, H. B., and Hoch, H. (1949). Unpublished.

McCarty, M. (1947). J. exp. Med., 85, 491.

McCullagh, E. P., and Lewis, L. A. (1945). Amer. J. med. Sci. 210,81 .

McFarlane, A. S. (1935). Biochem. J., 29, 1175.

McMeekin, T. L. (1940). J. Amer. chem, Soc., 62, 3393.

Milne, J. (1947). J. biol. Chem., 169, 595 .

Moen, J. K., and Reimann, H. A. (1933). J. clin. Invest., 12, 589.

Moore, D. H., Kabat, E. A., and Gutman, A. B. (1943). J. clin. Invest., 22, 67.

Moore, D. B., Pierson, D. S., Hanger, F. M., and Moore, D. H. (1945). J. clin. Invest., 24, 292.

Morris, C. J. O. R. (1944). Biochem. J. 38, 203

Nitshe, G. A., Jr., and Cohen, P. P. (1947). Blood, 2, 363

Oberst, F. W., and Plass, E. D. (1932). J. clin. Invest., 11, 123.

Oberst, F. W., and Plass, E. D. (1936). Amer. J. Obstet. Gynec., 31, 61 .

Oncley, J. R., Scatchard, G., and Brown, A. (1947). J. Physic. Chem., $51,184$.

Oudin, J. (1946). C. R. Acad. Sci., 222, 115.

Packalén, T. (1939). Acta med. scand., 100, 1.

Paic, M. (1939). Bull. Soc. Chim. Biol., 21, 412

Payne, S. A., and Peters, J. P. (1932). J. clin. Invest., 11, 103.

Pedersen, K. O. (1944). The Stedberg, 1884, 30/8, 1944. Uppsala, p. 490.

Pedersen, K. O. (1945). Ultracentrifugal Studies of Serum and Serum Fractions. Almqvist and Wiksells. Uppsala.

Perera, G. A., and Berliner, R. W. (1943). J. clin. Invest., 22, 25.
Perlmann, G. E., Glenn, W. W., and Kaufman, D. (1943). J. clin. Invest., 22, 627 .

Perlmann, G. E., and Kaufman, D. (1945). J. Amer. chem. S章. 67,638 .

Peterman, M. L. (1946). J. biol. Chem., 162, 37.

Peterman, M. L., Karnofsky, D. A., and Hogness, K. R. (194): Cancer, 1, 109

Pbillips, R. A., van Slyke, D. D., Dole, V. P., Emerson, K. Hamilton, P. B., and Archibal, R. M. (1945). Copper Sulph Method of Measuring Specific Gravities. Josiah Macy, Foundation. New York.

Philpot, J. St. L. (1938). Nature, Lond., 141, 283. Philpot, J. St. L. (1938). Nature, Lond., 141, 283.
Pillemer, L., Ecker, E. E., Oncley, J. L., and Cohn, E. J. (1941)

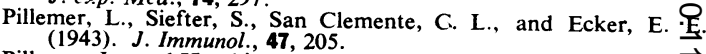

Pillemer, L., and Hutchinson, M. C. (1945). J. biol. Chem., 158, $2 \overrightarrow{99}$ Plass, E. D. and Matthew, C. W. (1926). Amer. J. Obstet. Gynees

Popjack, G., and McCarthy, E. F. (1946). Biochem. J., 40, 789. 융

Popper, H., Steigmann, F, Dyniewicz, H., and Dubi, A. (194\%.

Post, J., and Patek, A. J. (1942). Arch. intern. Med., 69, 67.

Rapoport, M., Rubin, M. I., and Chaffee, D. (1943). J. clin. Invest..

Rath, C. E., and Finch, C. A. (1949). J. clin. Invest., 28, 79.

Rennie, J. B. (1945). Amer. J. med. Sci., 210, 18.

Rimington, C., and van den Ende, M. (1940). Biochem. J., 34, $94 \frac{9}{1}$ Rutstein, D. D., Clarke, F. H., and Taran, L. M. (1945).' Scienee, 101, 669 .

Rytand, D. A. (1942). Arch. intern. Med., 69, 251.

Scadding, J. G., and Sherlock, S. (1948). Thorax, 3, 79.

Schade, A. L., and Caroline, L. (1946). Sciencc, 104, 340.

Schamberg, I. L. (1941). Amer. J. med. Sci., 201, 67.

Schick, B., and Greenbaum, J. W. (1945). J. Pediat., 27, 241

Seibert, F. B., and Nelson, J. W. (1942). J. biol. Chem., 143, 29. $\overrightarrow{0}$

Seibert, F. B., and Nelson, J. W. (1943). Amer. Rev. Tuberc., 47,

Seibert, F. B., Seibert, M. V., Atno, A. J., and Campbell, H. W0 (1947). J. clin. Invest., 26, 90.

Shapiro, B., and Wertheimer, E. (1946). Brit, J. exp. Path., 27, 22 Shapiro, S., Ross, V., and Moore, D. H. (1943). J. clin. Inves

Shedlovsky, T., and Scudder, J. (1942). J. exp. Med., 75, 119.

Shemin, D. (1945). J. biol. Chem., 159, 439.

Sherlock, S. P. V. (1946). J. Path. Bact., 58, 523.

Shortt, H. E., Garnham, P. C. C., Covell, G., and Shute, P. () (1948). Brit. med. J., 1, 547 .

Sinclair, H. M. (1948). Proc. R. Soc. Med., 41, 550.

Smith, E. L. (1946). J. biol. Chem., 164, 395

Stacey, R. S. (1947). J. Lab. clin. Med., 32, 1002

Stern, K. G., and Reiner, M. (1946). Yale J. Biol. Med., 19, 67.

Surgenor, D. M., Koechlin, B. A., and Strong, L. E. (1949). J. cli

Surgenor, D. M., Strong, L. E., Taylor, H. L., Gordon, R. S., J and Gibson, D. M. (1948). J. Amer. chem. Soc. 71, 1223 .

Svedberg, T., and Pedersen, K. O. (1940). The Ultracentrifugê Clarendon Press, Oxford

Svensson, H. (1939). Kolloidzschr., 87, 181.

Svensson, H. (1941). J. biol. Chem., 139, 805.

Svensson, H. (1946). Arkiv. Kemi. Mineral Geol., 22a,

Tierney, N. A., and Yeomans, A. (1946).J.clin. Invest, 25, 822 .

Tiselius, A. (1937). Biochem. J., 31, 1464. Cln. Invest., 25, 822.

Thorn, G. W., Armstrong, S. H., Jr., and Davenport, V. D. (1946). J. clin. Invest., 25, 304 . Thorn, G. W., Armstrong, S. H., Jr., and Woodruff, L. M., and
Tyler, F. H. (1945). J. clin. Invest $t$, 24, 802.

Thovert, J. (1914). Ann. Phys., Ser. 9, 2, 369. Treffers, H. P., and Heidelberger, M. (1941). J. exp. Med., 73, 12 .
293.

Treffers, H. P., Moore, D. H., and Heidelberger, M. (1942). J. exN Med., 75, 135 .

Trevorrow, V., Kaser, M., Patterson, J. P., and Hill, R. M. (1941)
J. Lab. clin. Med., 27, 471 .

Van der Scheer, J., Wyckoff, R. W. G., and Clarke, F. H. (1940)

Volkin, E. (1949). J. Immunol., 61, 143.
Volkin, E., Neurath, H., Erickson, J. O., and Craig, H. W. (1947) Amer. J. Syph., 31, 397.

Wallis, A. D. (1946). Amer. J. med. Sci., 212, 713,

Widdowson, E. M. (1933). Biochem. J., 27, 1321. 